CIHM Microfiche Series (Monographs)

\section{ICMH} Collection de microfiches (monographies)

\footnotetext{
Canadian Institute for Historical Microreproductior.s / Institut canadien de microreproductions historiques
}
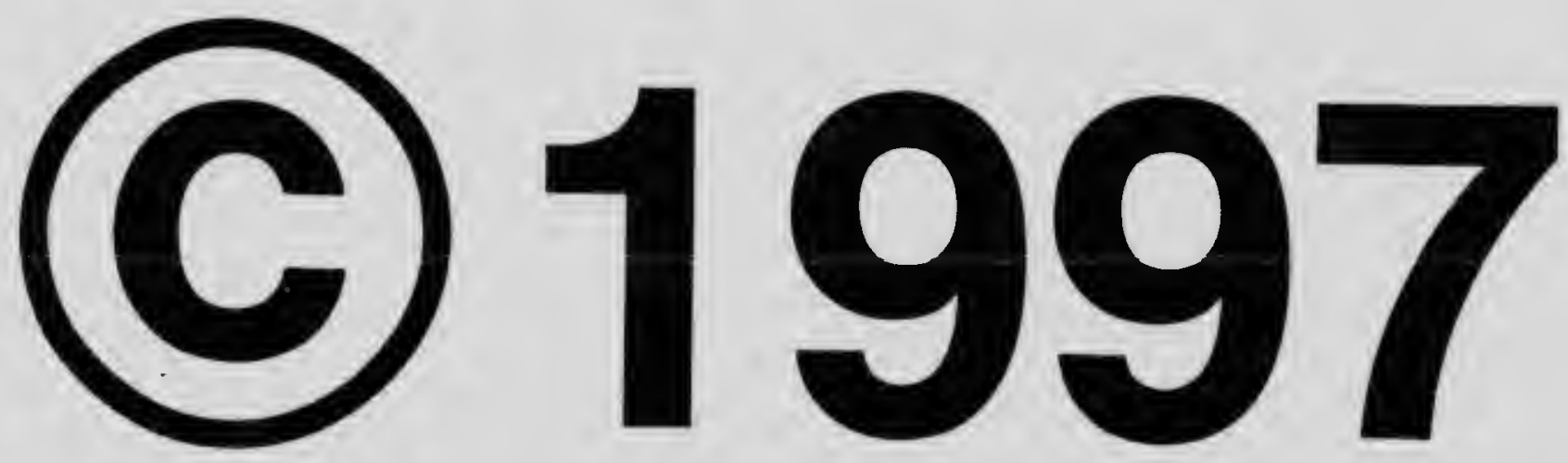


\section{Technical and Bibliographic Notes / Notes techniques et bibliographiques}

The Institute has attempted to obtain the best original copy avallable for filming. Features of this copy which may be bibliographically unique, which may alter any of the images in the reproduction, or whlch may slgnlficantly change the usual method of filming are checked below.

\section{Coloured covers /}

Couverture de couleur

Covers damaged /

Couverture endommagée

Covers restored and/or laminated /

Couverture restaurée et/ou pelliculée

Cover title missing / Le titre de couverture manque

Coloured maps / Cartes géographiques en couleur

Coloured ink (i.e. other than blue or black) /

Encre de couleur (i.e. autre que bleue ou noire)

Coloured plates andior illustrations /

Planches et/ou illustrations en couleur

Bound with other material /

Relié avec d'autres documents

Only edition available /

Seule édition disponible

Tight binding may cause shadows or distortion along interior margin / La reliure serrée peut causer de l'ombre ou de la distorsion le long de la marge intérieure.

Blank leaves added during restorations may appear within the text. Whenever possible, these have been omitted from filming / II se peut que certaines pages blanches ajoutées lors d'une restauration apparaissent dans le texte, mais, lorsque cela était possible, ces pages n'ont pas été filmées.

Additional comments /

Commentaires supplémentaires:
L'Institut a microfilmé le meilleur exemplaire qu'il lui a été possible de se procurer. Les détails de cet exemplaire qui sont peut-être unlques du point de vue bibliographlque, qui peuvent modifier une image reproduite, ou qui peuvent exlger une modification dans la méthode normale de filmage sont indiqués ci-dessous.

Coloured pages / Pages de couleur

Pages damaged / Pages endommagées

Pages restored and/or laminated /

Pages restaurées et/ou pelliculées

Pages discoloured, stained or foxed /

Pages décolorées, tachetées ou piquées

Pages detached 'Pages détachées

Showthrough / Transparence

Quality of print varies /

Qualité inégale de l'impression

Includes supplementary material /

Comprend du matériel supplémentaire

Pages wholly or partially obscured by errata slips, tissues, etc., have been refilmed to ensure the best possible image / Les pages totalement ou partiellement obscurcies par un feuillet d'errata, une pelure, etc., ont été filmées à nouveau de taçon à obtenir la meilleure image possible.

Opposing pages with varying colouration or discolourations are filmed twice to ensure the best possible image / Les pages s'opposant ayant des colorations variables ou des décolorations sont filmées deux fois afin d'obtenir la meilleure image possible.

This hem is flimed at the reduction ratio checked below I

Ce document eat filmb au taux de réduction Indiquét ci-dessous.

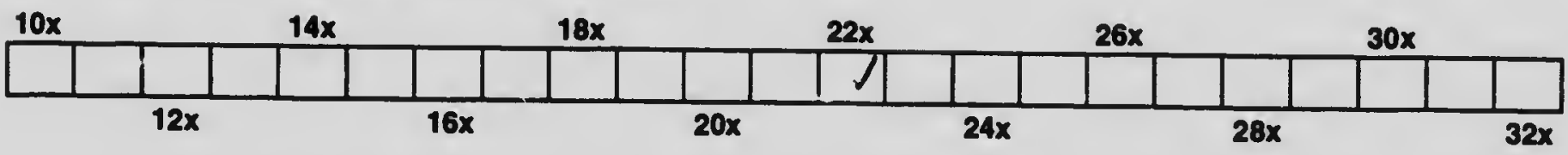


The copy flimed here hes been reproduced thenks to the gene: oslty of:

\author{
Library \\ Agriculture Canada
}

The imeges eppeorlng here ore the best queilty posaibie considering the condlion end iegibility of the originei copy end in keeping with the fiiming contrect speciflcetlons.

Originei coples in printed paper covere are filmed beginning with the front cover end ending on the iest pege with e printed or lilustreted impression, or the beck cover when eppropriete. Ail other orlginei copies ore flimed beginning on the first pege with e printed or illustrated impression, ond ending on the iest pege with a printed or lilustreted impression.

The lest recorded freme on eech microfiche sheil contein the symbol $\rightarrow$ Imeening "CON. TINUED"), or the symboi $\nabla$ (meening "END"). whichover eppiles.

Meps, pietes, cherts, etc.. moy be flimed ot different reduction retios. Those too ierge to be entireiy inciuded In one exposure ere filimed beginning in the upper loft hend corner, ioft to right end top to bottom, es many frames as required. The following diegrems illuatrete the mothod:
L'exempieire filimb fut reproduit grace a ia gónórosité de:

\section{Bibliothdque}

Agriculture Canada

Les Imeges suivantes ont st'b reproduites avec ie pius grend soin, compte tenu de !e condition at de ia nettets de i'axempielre filimb, at en coliformits evac les conditions du contret de filmage.

Les exempielres originaux dont ie couverture en pepier est imprimce sont flimés en commencent per ie premier piet et en tarminent soit per ie dernibre pege qul comporte une empreinte d'Impression ou d'iliustretion, soit per ie second piet, soion ie cas. Tous ies eutras exempieires origineux sont filmśs en commençent per le premiòre pege quil comporte une empreinte d'impression ou d'iliustretion et en terminent per le dernitre pege qui comporte une telle emprointe.

Un des symboies suivents eppereîtra sur io derniàre imege de cheque microflche, selon le ces: ie symboie $\rightarrow$ signifie "A SUIVRE", is symboie $\nabla$ signifie "FiN".

Les certes, pienches, tabieeux, etc., peuvent être flimbs a des taux de róduction difforents. Lorsque ie document ast trop grend pour stre reproduit on un seui clichb, il est flimb pertir de i'engie supérieur geuche, de geuche droite. ot de hout en bes, en prenent ie nombre d'imeges nócesseire. Les diegremmes suivents iliustrent ie mothode.

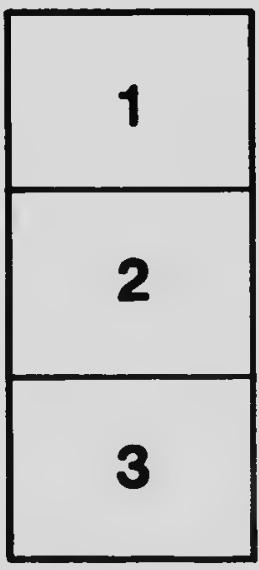

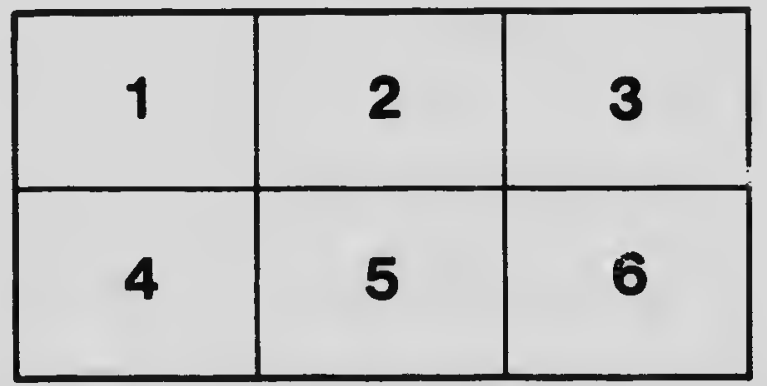




\section{MICROCOPY RESOLUTION TEST CHART}

(ANSI and ISO TEST CHART No. 2)
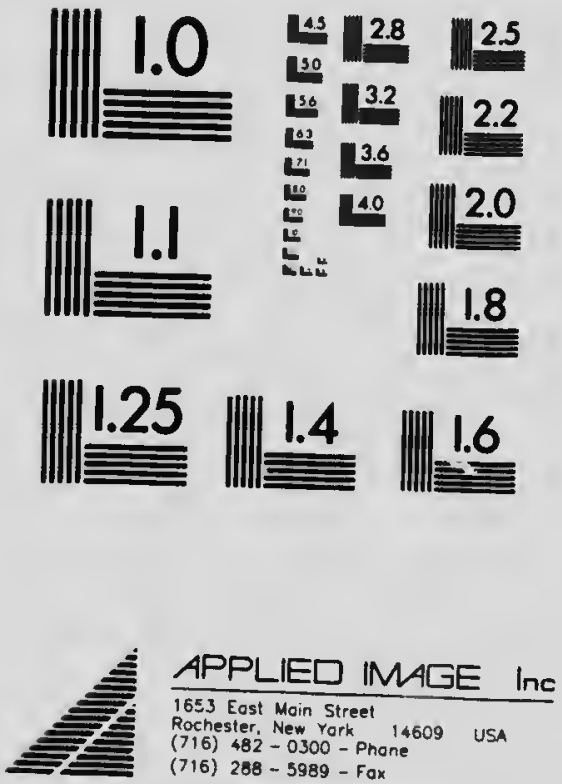


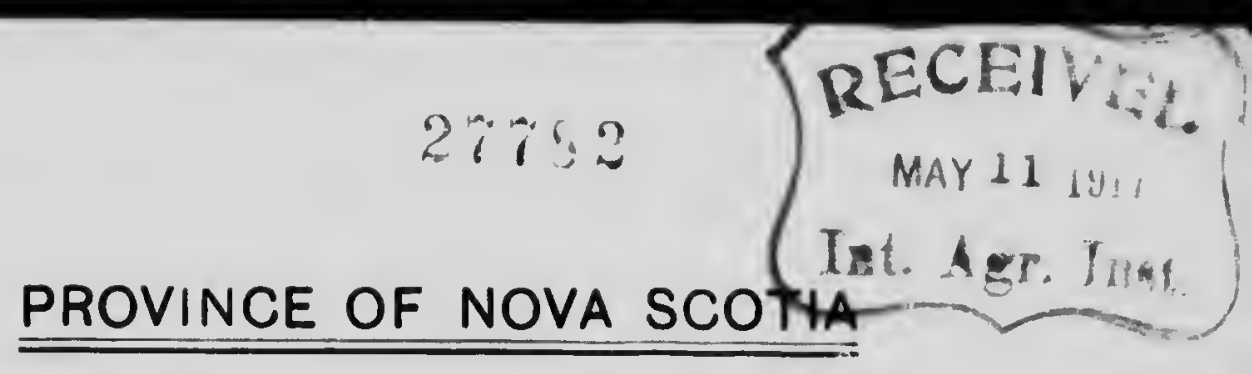

\section{DEPARTMENT OF AGRICULTURE}

BULLETIN NO. 8.

The Green Apple Bug in Nova Scotia. -BY-

W. H. BRITTAIN,

Piovincial Entomologist.

Published by Order of the Legislature.

January, 1917. 

Government of Novas biotin.

(Offices of Agricultmor.

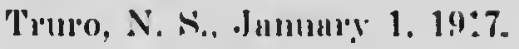

To the Hon. George 11, Murray, Provincial Socerotury, Ilulifux, N. s.

Sir :-I have the honor to transmit Bulletin No. s, entitled, "The Green Apple. Bug in Nova Scotia", and helprith reconmend its publication al distribution.

I have the honor to be, sir, Your obedient servant,

M. CLAImING.

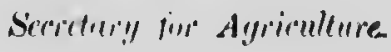





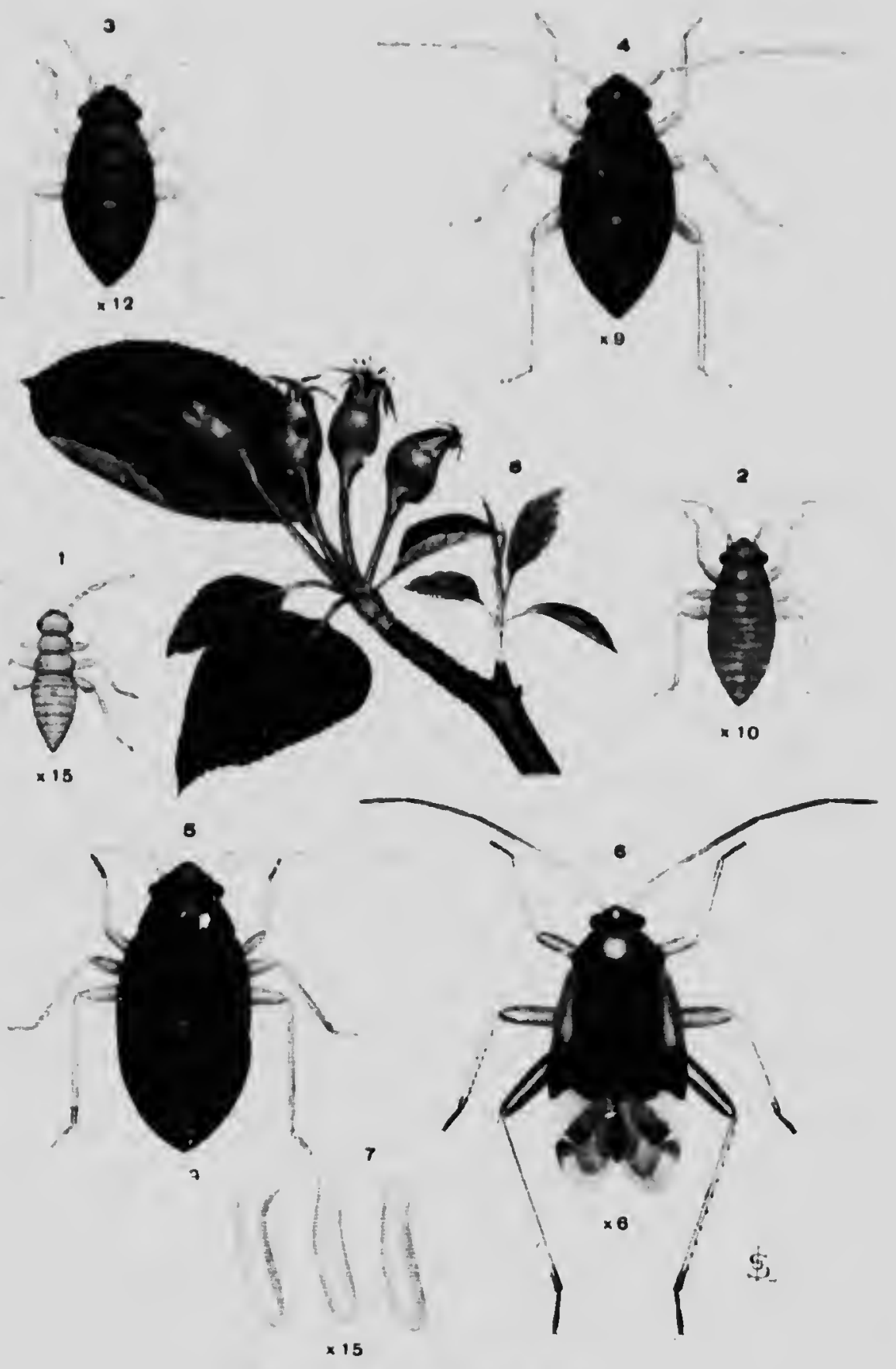

THE GREEN APPLE BUG

(LYOUS COMMUNIE VAR. NOVAECOTIENEIE KNIGHT) 


\title{
The Green Apple Bug in Nova Scotia.
} - BY -

\author{
W. H. BRIITAIN.
}

\begin{abstract}
EXPLANATION OF COLORED PLATE. - Fi!mir* $l, \therefore \quad \therefore$,

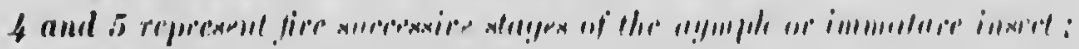

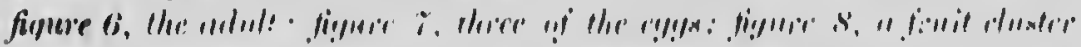

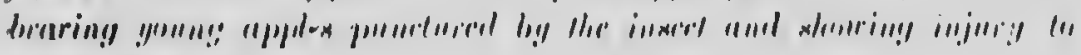
youn! leirrin,
\end{abstract}

\section{INTRODUCTION.}

The investigntion of iel this hulletin is the resmlt, las

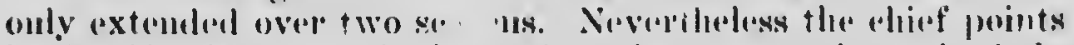
in the life history of the ilsecet have been worked ont, its hal)-

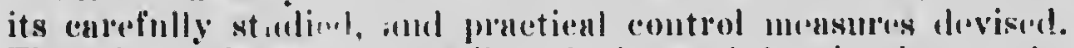
"There is, doubtless 'much still to be lemued, but in viow 6 : M1,

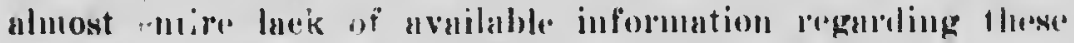
matters, it enemed best to offer this information to the pmblire at the present time. The result of further work wi!l he isisted in ciremlur form as it is completeml.

\section{GENERAL SUMMARY.}

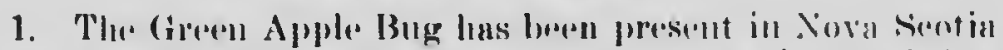

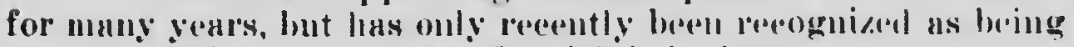
responsible for the damage of which it is the callse.

2. Its injury is widespremel in the conntios of Lants, Kings, Ammpolis und llighy, und it is possibly present in oflece counties, us woll ..3 in the province of l'rince Fulwad Istand. 
3. It is, where present, the most serious enemy of the frnit-grower, and while not so general as some other pests, the. damage that it cloes is most swerping and the inseet most diffienlt to "l'ullicate.

4. The insect has only been foumel to breed on the apple, pear and quinee, thongh in the immature, or nymphal stages, it feeds on varions other plants and in the adult state frequently attacks plums.

5. The inseet, when newly hatehed, resembles a small yellow aphis in appearaner thongh much more aetive. As it increases in size it becomes bright green and finally reaeles the length of one-sixth of an inch. It then monlts and assumes the adult or winged form. It is then a fragile insect with relativeiy long legs and antemnae, and in eolor a combination of ligtht and dark brown. In this stage it closely resembles the common tarnished plant bug (Lygus pratensis Limn.)

6. The young begin to emerge several davs before the blossoms open, the maximum emergence coineiding with the period of finll bloom of the Bartlett pear, or just as the Gravenstein blossoms begin to open. The nymphal stage is of abont 32 days duratio:ı. The adnlts begin to clie off within a conple. of weeks after reaching maturity, but are fomm in diminishing numbers throughout the summer and early autumn. The winter is passed in the egg state, belleath the bark of the twigs.

7. The young bugs or nymphs are very active and elusive in their habits and as they increase in size, exhibit an inereased tendency to drop to the gromnd. Leaves, stems, blossoms and fruit are freely attacked, but blossoms and frnit are preferred. They are occasionally predaceous in habit, and though apparently fragite, can exist for several days without food and are able to make their way over the ground for comparatively long distances.

8. The adults are active insects and strong fliers, thongh, under ortinary conditions, they do not appear to wander far from the orchard in which they have developed. In feeding, the adults prefer a diet of fruit, and that of pears is inost at. tractive to them when they first reach maturity.

9. The first injury to the apples appears as small purple. spots upon the leaves, which, as the leaf grows, develop into. small perforations. The new succulent shoots are also injured,. 
and in severe cases wilt and dice. The blossons are freely attacked as soon as they appear, amel as a result they also shrivel up and ale. Injury to the young fruit is first show loy benity of sup oozing through the skiu, later by a reclelish pimple". marking the spot. A large proportion of the injured appless drop to the gromel, otlerwise they are bally searled and twisted. Continnel severe attacks result in a gralnal weakening of the vigor of the trees. Injury to the cuinere resembles that of the apple, but is not so severe.

10. Thongh the insect breesls on the pear to a certain axtent the greatest injury to the fruit of this tree apjears to be caused by achults that fly to the pears from infested apples. Their injury eanse musightly brown, eorky scars upon the fruit, and hard, flinty kernels extending into the pulp. Sincli fruit has been popularly known as "woody pears."

11. Plums are also injured by adults flying in froul o:1tside, eansing an exulation of colorless gun from the infustal fruit.

12. Nymphs that fall from the trees are capable of completing their development on varions weeds and grasses growing in the orchard.

13. The insect aids in the spread of and increases tine losses from European Canker (Nectria ditissima) and is il carrier of Fire Blight (Bacillus anylovorns).

14. Observation and experience has shown that, while of all varieties of apples, the Noupareil (Roxbury Russet) suftirs most severely, others approach it in susceptibility, while none appear to be immmne. Anong pears Bartletts ismally sntfar .nost.

15. Conditions favoring increase are heavy shate, pone air circulation and lack of clean eultivation in the spring and carly summer. Destructive ontbreaks may ocenr, howevel, under a wide range of conditions.

16. Natural enemies have not yet been found to play in important part in the control of tlee pest, though ants and spicl. ers destroy a certain number.

17. The control of the insect is made difficult by its elusive habits, by its ability to hide in inaccessible places. by the .density of the foliage at the time the spraying must be clone, 
and by the fact that many of the bugs fall off the trees, only to make their way back again after the spraying is finished. The following methods have been found effective:

(a) The trees must be properly prunet and must not be too elose togetlere, so that all parts a re readily accessible to the spray.

(b) The trees shoult be banded with tree tanglefoot presvious to spraying wlerever the insects are numerous, to prevent the reascent of those insects that have fallen to the ground. If the insects could be sprayed within a few days of emerg. ence this would not always be necessary, but owing to the period over which they are emerging, to possible delays die to wet weather, and to the length of time required to spray an orehard of any size, some insects might be well grown before it was possible to spray the whole orchard. Again, if the orehard could be larrowed immediately after spraying banding. might be dispensed with, but this is not often possible.

(c) Apple trees should be sprayed with nicotine sulphete (Blackleaf 40) just before the blossoms open, and, if nceessary, again just after they fall, using a strength of from $3 / 4$ of a pint to 1 pint for eacl 100 gals. of spray. The weaker strengths may be safely used, especially for the earlier spraying, provided the material is properly applied. Since pears are most seriously infested by adults flying from nearby apple trees, the remedy for pears is, first of all, to spray the infested apples. For pear trees infested by the nymphs, one spray just after the blossoms have fallen is usually sufficient.

(d) A very heavy, drenching, llriving spray is necessarv, that will reach all parts where the bug is likely to hide. Best results were obtained by the use of a drive nozzle and a pressure of not less than $175 \mathrm{lbs}$. Spray each limb iudividually from every angle, taking particular care that the centre and top of the tree is given just as thorough treatment as the outside. Do not be afraid of "wasting spray" or failure is certain to. result.

(e) All these precautions if properly carried out, cannot fail to control the pest, but neglect of any one of them may result in complete failure. 


\section{HISTORY.}

For many years past, so-ealled "wooly pears" have be:n known and commented npon by fruit growers throughout the Annapolis Valley, such pears being covered witl corky disfiguring sears, so as to be rendered quite worthless. This tronble, which has ammually destroved a very large proportion of the pear erop, was eommonly aseribed to lack of iron in the soil, and not nncommonly liberal applieations of iron filings were made to remedy this eonclition, but naturaly without resnlt.

Within the past ten yoars an increasing number of $0 t^{\circ}$.hards that formerly bore heavy erops, have been gradually going back, until they finally yield only gnarled and twisted apples, or in some eases, none whatever. Further investigation has shown that a number of orchards have grown up and eome to bearing age without ever vielling a erop of fruit, or oily furut of the inferior kind already deseribed. This state of atfairs was all the nore puzzling to the fruit-growers, since such trees almost invariably eame into blosson each year. The

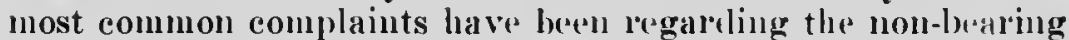
of the Nonpareil (Roxbury Russet), but examination showed that the trouble was not by any means eonfined to this varie!y, though it uncloubtedly sutfered as severely, or morte severoly, than any other.

No one appenrs to have suspereted that the trouble in the apples had any eonneetion with that of the pears, or that either was of insect origin. In .June, 1914, the writer visited in orchard uear Wolfville, $\mathbb{N}$. S.. eonsisting of mature troms of various standard varicties, inchuling Nonpareils, Ribston. Gravenstein, Golden kusset, as well as seveloal valpieties of pears. 'Tlle ownel' stated that the orcharce lial been gradlally going back for the past ten years, that lor at lobst six regrs the Nonpareils had borne no erop, and that the tromble hal gladually spread to the other varieties; until they too hacl exats-

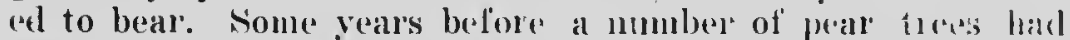
been eut down, beeanse the fruit persisted in "groming wooly", and those that remained were" all going the same way every year. All the ordinary sprays had been tried, variels fertilizers were applied, and the oreliarel moler-elrained in an effort to arrest the trouble, which, however, steadily grew worse. In faet, though this oreharel was one of the best carredfor in the Valley and was formerly a splendiel producer, it liad at length reached the point where no erop at all was being i:"oduced. An examination of the trees showed them to be swant- 
ing with green nymplis of the insect now popularly known throughout tho Anmapolis Valley as the "Green Apple Bug", and a carefinl stucly of the feeding labits of the insect proved conclusively that it was the real culprit. For the past two seasons observations have been taken inl nany similar orebards thronghout the province, and further investigations have conly temeled to continn onr earlier conclusions.

\section{DISTRIBUTION AND SPREAD.}

The pest seems to be well listributed throughout the fruitgrowing centres of Nova seotia and also where apples are lot grown to any extent commercially. Mlore or less severe infestations have been located throughout the eounties of llants, Kings, Annapolis and I Jigby, and i. pieal "rooty pears" have also becell sent in from Prinee Edwarel lslanel. It would at first secell that the pest was Inole widely tistributed on pears than on apples, the plirase " injury to pears only" oecenring wial! considerably frequency in the reports of the entomological inspectors. This, however, is probably due to the fact that whereas most of tho injureal pears remain elinging to the tree, the apples are largely destroyed while still in the blossom stage and later a large proportion of the injured apples drop to the grominl.

Though experinents have shown that the achlts are capalble of flying consitlerable distances, the pest nppenes to spreat 'yut slowly from oreharel to orehare. Orcharels in close proxingity to one anotler vary greatly in their elegres of infestation. Contimued olservations labe slown that a light but miform infestation may suldenly develop into a very severe one, from one season to the next. Growers shoulel therefore keep careful watch to discover any incipient outbreak before it has till:s to elevelop to smele an extent as to menace the cropl.

\section{SERIOUSNESS CF PEST.}

Sutficient has already been written to indicate that this insect is a very serions pest of the apple ancl pear, but any estimate of the actual alamage would, of course, be out of the question. Though as yet many oreharels are still free or comporatively loe trom attack, it is nevertheless a fact that where the green apple bug las become established, there is no pest to compare with it, either in the amount of clamage clone or in the difficulty that is experienced in controlling it. The pears in many orcharcls have for years been so scarred as to be quite 
mmarketable and in momerons apple orelarels the erop has been greatly reeluced, or "ven elestroperl. Finthere than this. tha" vitality of many trees las been serionsly impared and finit spmes cither killeel or remeleperl useless from the attacks of the insect. Jany growers who, two years ago nevere knew of the rexistence of the pest, will now stute conficlently that it is the worst insecet with which ther have to eontemel.

The apple erop in the Annapolis Valley las not heen inereasing at the rate one would experet from the new alemenge

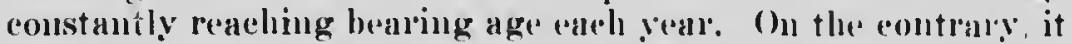
serems to have, on the whole, actually gone back. 'Tlere is litthe doubt in the minel of the writer that this eondition of all ail's can be to a large extent laiel at the toor of the grean apple. bug. In any ease there can be no cloubt that nimmloupes of growers will have to abanton apple growing, if they al.) net bring this pest meler ecutrol.

\section{HOST FLANTS.}

As far as we have determined, the insect only blecels in the apple, pear, quiner, f:mel possibly the lose. Yonng nymplis were fouml in consicierable numbers feeding on rose hinshess planted in sod, ant about twenty feet from the nearest applos tree, but it is quite possible that the insects fell from the tion and mate their way over the gromul to the rose bushes. Ninglis were also found on a young elm tree benenth infested apples, but though ehn trees are abumblant near infested orehards, his is the only case in which we have fomel them infested hy th.. insect.

When shaken from the tree, the nymplis have bean nbserved to feet upon a large number of werels and gratse.s growing benenth the tree, but on reaching the atult stage : ?: invariably seek the apple, pear or quince to forel and cleposit their eggs.

\section{THE INSECT.}

The young insects, or nymphs, are pale: yhtly yellowish insects about $1-25$ of an incle long when $f_{21}$ hatehed. In the third nymphal stage they become a bright green and will full grown are slightly yellowish about the head and thorax, measuring about 1-6 of an inch long. The athelt is a lelie:ite insect $1 / 4$ of an inch long. When newly merget it is quite pale in color, but later becomes a combination of light and rark browns, though individual insects vary gleatly as regurds 
color. In appearance it bears a close resemblance to the tarnished plant bug (Lygus pratensis Linn), for which it is froquently mistaken.

\section{IIP EISTORY.}

The first nymph to be found emerging in the orchard in 1915, was on May 24th, and the last on June 10th. In 1916 the first one was taken on May 18th, but they were not found hatching in numbers until Mry 24th, the date of maximum: emergence being about the first of Jume. That is to say, the period of greatest emergence of the bug from the egg stage occurs. just when the blossoms of the Gravenstein apple begin to open, or when the Bartlett pears are in full blown. By far the gruater number of insects hatch at this time, though a few belated individuals keep emerging throughout the blossoming period.

\section{FIG. 1.}

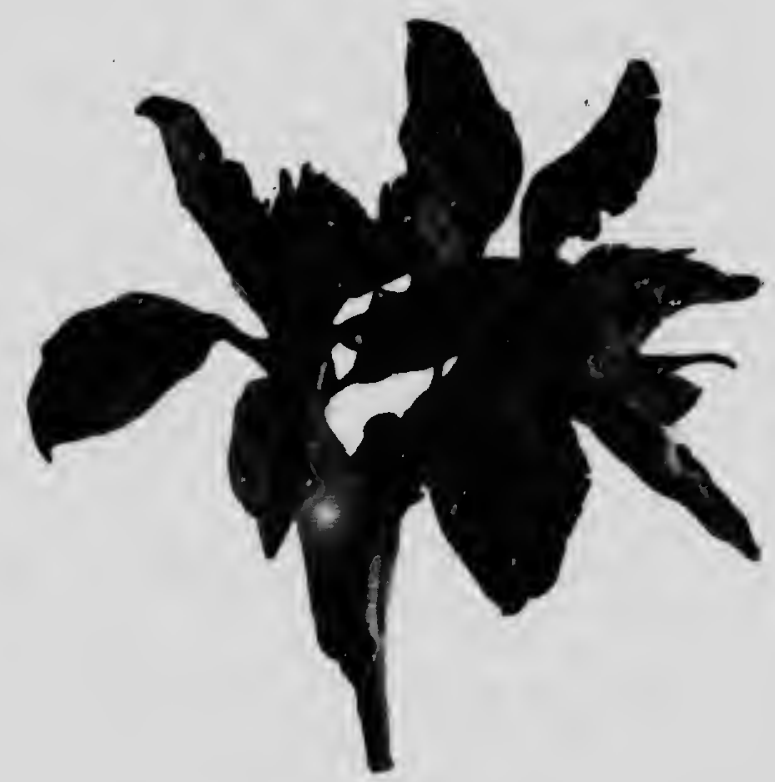

Condition of Gravensteln blossom buds when the first bug was found emerging in the orchard. 
The nymphs seem to energe simnltaneously on both early and late varieties, but keep emerging for a longer perioul froin late varieties such as the Nonpareil. The cluration of the first nymphal instar is 5.22 days (avirage of 52 intliviluals); of secund, 5.43 days (average of 34 individuals); of the third, 6.66 days (average of 34 individuals) ; of the fourth, 6.77 days (average of 24 individuals), and of the fiftl, 6.83 iays (average of 12 individuals).

In 1915 the first adults were taken on Jume 27 th, most of the nymphs becoming .mature by July 5th. In all the time that this insect has been "umler observation, no nymplis have been observed later than the first week in Jilly, all having completed their transformation by that clate. The length of the adult stage varies greatly, single indivieluals laving been taken in the oirchard as late as the last of September. During the season of 1915 adults were first taken on June 2:3rel, the greater number reaching the atult stage by July $3 \mathrm{rtl}$.

The accompanying table gives the detuils of the life hiztory of 12 individuals which were reareel from the rgg stage to the adult stage during the season of 1915: 


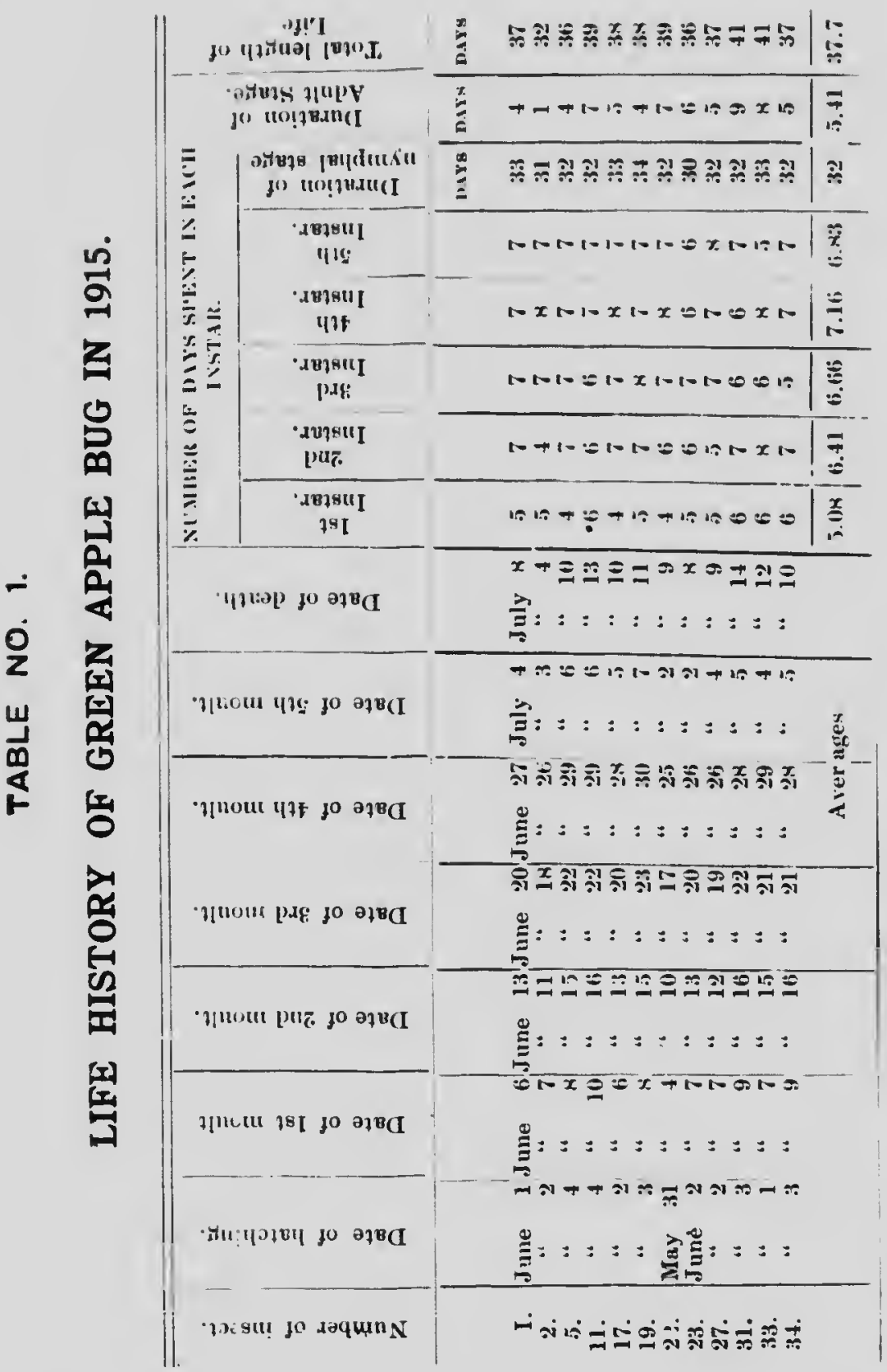


The duration of the nymphal stage in our open air iusent.

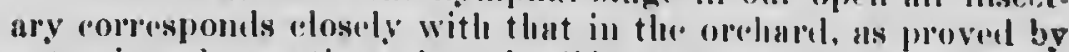
extensive olservations, hut the life of the atult insect muler matural comditions is molnch longer than the inseretury perourts wonld serem to imliente. Repeated experiments slow that the melults will not thrive in confinement, but k(e)p Hying peestlessly ubont, Intil they die of exhunstion. For the first werek or ten

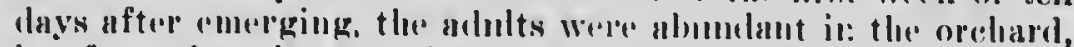
but frout that time on they began to alie oft' antite mapidly. It was an ensy matter doring this time to find a mumber of dead bugs fasterled along the Imillils of a single apple leaf. The bugs have a habit, when alsout to die, of extrutling the combal extrenity of the alinentan'y eanal, which is rovered by al viseid

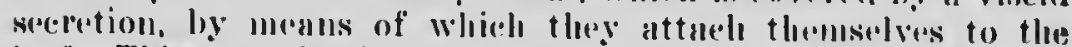

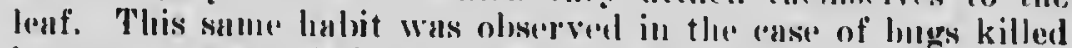
by our sprays. A large proportion sturek fluemeselyes to the

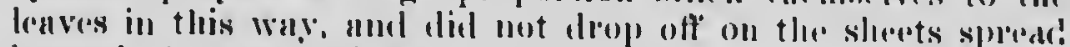
benesth the trese intil soliac homes latere.

Thongh large numbers of bugs died during the latter part of July, 1915, there was uo eliffientty in fimting specinens thronght the montly of Angust mul early Septrinber. After that, individual speecimens conlel only le located with difficulty.

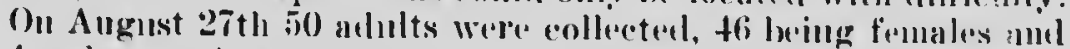

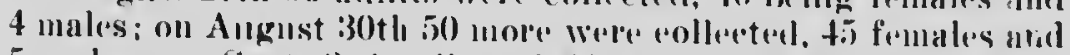

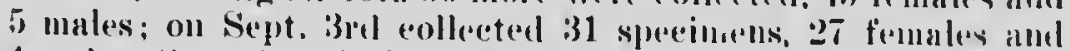

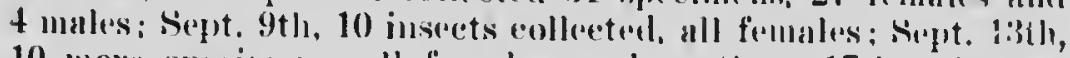
10 more speedinens, all females, and onl sept. 17th only iwo

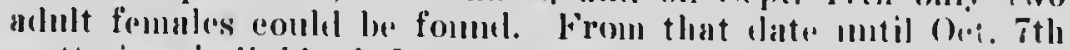
seattering individual females lave beroll taken. Sinuilal chservations were made in 1916, the alult inserets being munn: cons

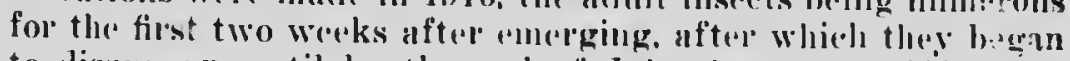
to disupperar, mutil hy the ent of July they were diffiente to fintl.

\section{EGG LAYING.}

The eggs are deposited beneath the bark just withi!l the cambinm layer of prars, apples, quinces and possibly pooses, commonly in the fruit spmrs. By far the greater number are deposited in the twigs of the apple, even thongh other host plants are abunclant. In many oreharels suffering from a viry severe infestation, we have failed to find any nympls hate hing on the pear trees, and while it is true that they frequently do breet in the pears, we liave never fomnd them in such immense 
numbers as they are commonly foumd on the upple. Most of the ege luying is clone doring the montl of July, but it esu-

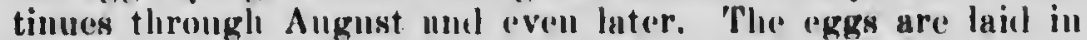
fruit spurs, suckers, whter spronts uncl other twigs.

\section{HABITS OF NYMPHS.}

The immature insocts, or nymphs, us they are calleal, of this speeces, are extremely ehusive in their habits, which do obtless explains the fuct thit though their work has been kw: iru for many years they themselves linve ouly reently been connected with it. When disturbed they rou with great rapidity, hiding themselve:s in the uxils of leaves, inside a cenrled leat, inside the blosson's, hetwern the hlossom pedicels, or in a'ly place that affords concenlument. The young nymphs do not readily ilrop to the gromul. and are not washeel off to uny gorent

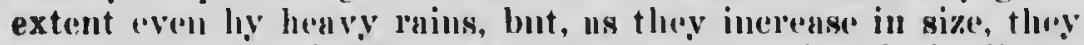
exhibit un incrensing temlency to drop when disturbed. Whin trees infested with the hugs are spresyed at "time when the insects are over lialf grown, the hacks of the horses are sonicetimes green with the nymphs that drop from the trees. (Bur observations slow that first and second st uge nymphs will run rapidly in an attempt to concenl themselves when disturburl,

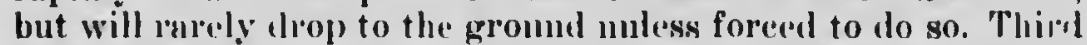
stage "uymphs show a temelency to clrop. While fourth and fifth stuge ny,mplis cloop still more renclily.

The mewly latehere nymphs seen to profere the folinge of apple and peris, but will ilso pmetmere the tender tivigs, partieularly snekel's und water sprouts. As soon us blossoms and fruit are available the bugs cluster on then, though attarking

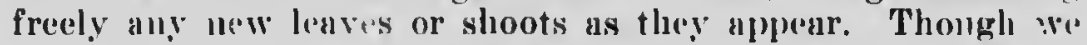
have reilied the inseet throngh to the ahnlt stage exchusisely"

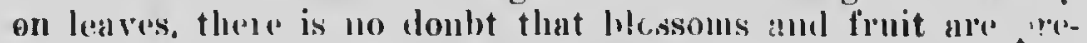
ferred, and they can only witl difficulty bo inclueed to fored on matmo leares. 'The finit clusters are a lavorite place for the nymples to work and when the blossom pedicels are still fastened together they work theil way in between them in large numbers for the purpose of feeding. As soon as the blossom petals begin to open ont, ancl before they have spread apart, the young insects begin to make their wy inside. After a heavy rain at this: ", it has been observed that the insects are (oj)parently les. anclous about the trees. A careful exaninintion slows t!iui large mumbers of them have made their way into the blossoms, where they hay likiten themselves umong 


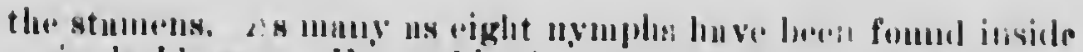
" single blossom. From this timb an the ir attrution is nlmost

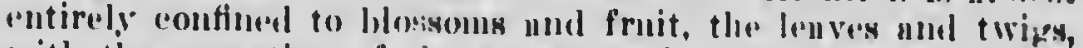
with the "xecpition of the new growth, heing nltageilese forsukell. Where the set of fruit on $n$ tree is light, II very few luge will soon destroy it all, and then, no further foot lesing uviluble, fored upon lenve's und tender twigs. In forfling, the

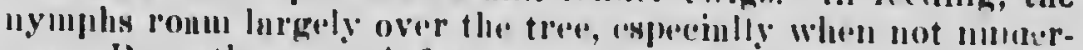

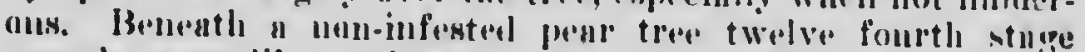

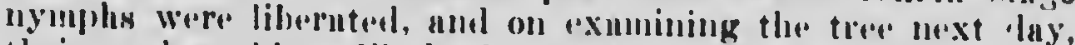

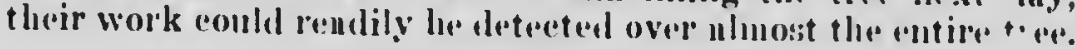

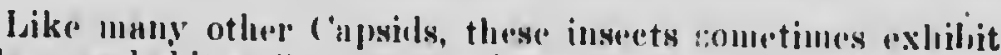
prealaceous liahits. On onc oecasion a number of nymples were ohserved repentedly theusting their hent. into the lurven if a

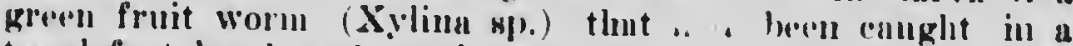
tanglefoot huncl, nnd continnerl to so so until the enterpillus

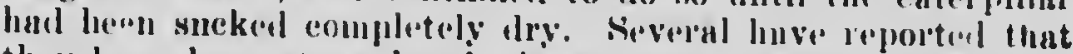
they have been stumg by the insect welen passing henoat! IIfestod treas. If left mirlisturhed it will sombetimes piedere the skin several times, mal remuin foeding mmil comp!rotely gorged with hlood.

For such mplarently frugilo insects tl: myuphs ure renarkuhly strong and active, and, as will la licreinaftor ex-

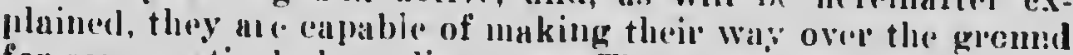
for comparutively long listunces. Tlay ure also abla to undergo somewhat molonged perious of starvition. Living lings have heren fombl on twigs that were collecial and helut withont winter for two wereks, though doring mest of that tianes it must have heen inpossihle for them to extruct any nourishucent from the dead dio twigs.

\section{HABITS OF ADULTS.}

Like the nymplis the udults are very active, ant they take to flight rendily when disturbed. By stumbling in a leravily :nfested orehard on a bright day they can be masly olserved tyying ubout in the sinlight. Like the nvmples they are also very shy, und when upprouching a tree :he! (l)e insects are observerl clustering on the fruit, they will he seen to milive their way quickly uround to the opplosite side, and tate to flight if molested further. In colel, tull or laim weatier they are more sluggish, and (Irop on slight provocution, though they usually take to flight before striking the gromill. 


\section{plate I.}
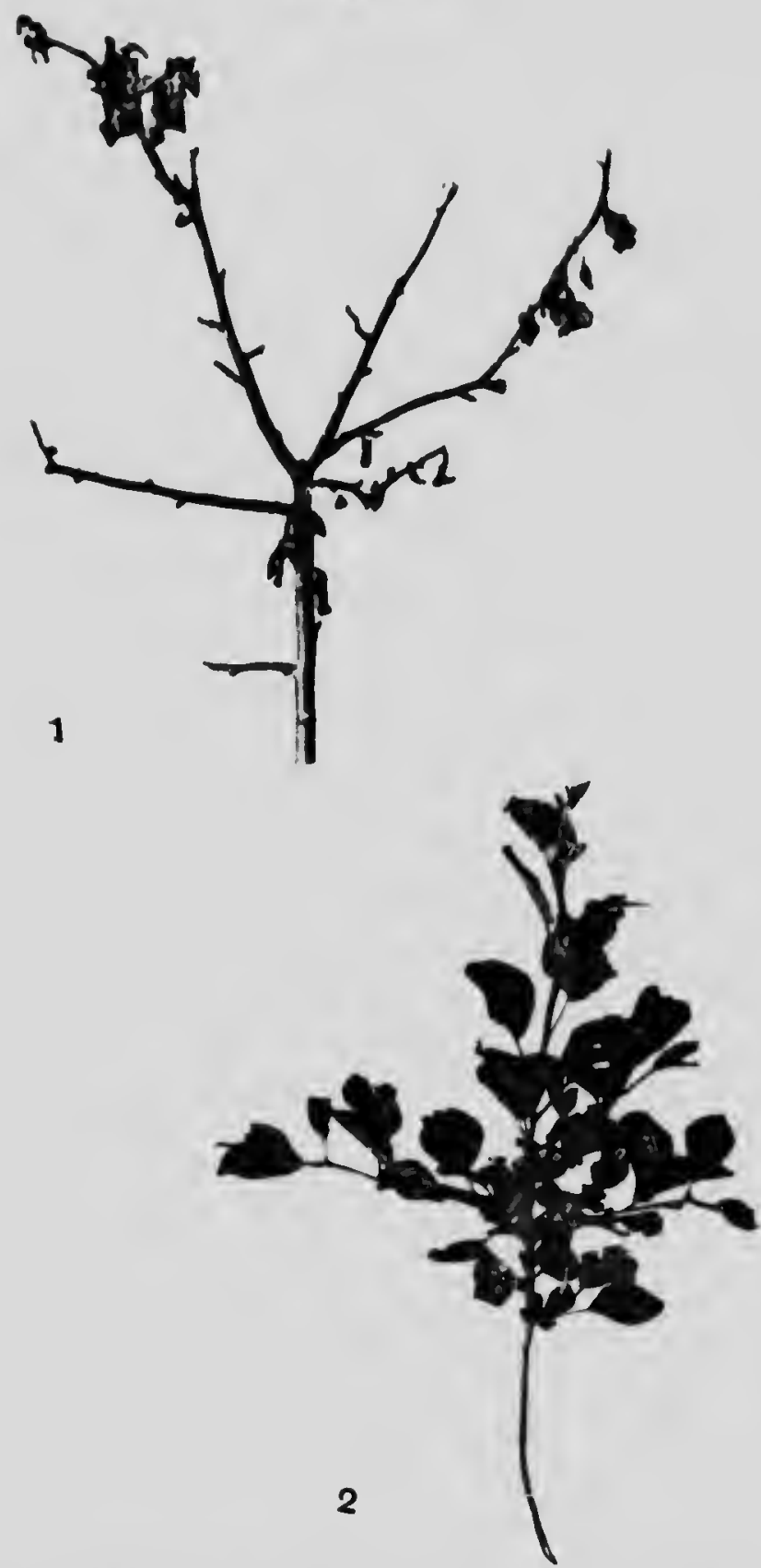

Fig. 1.-Appearance of apple ccedilng upon which a large number of bugs had tcen allowed to fced. Mect of the leaves withered and diopped. (Orlginal.)

Fig 2,-Check seediling. (Original.) 


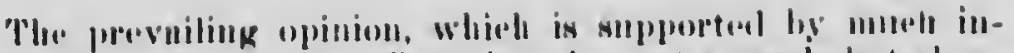

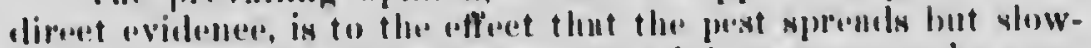

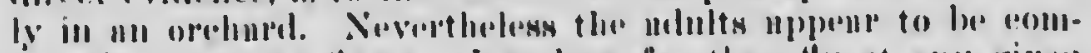

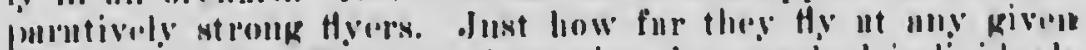

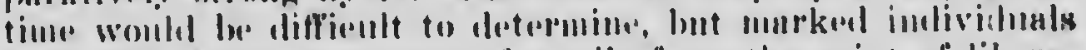

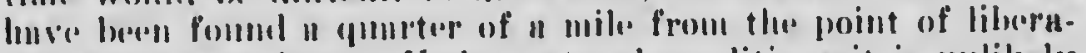

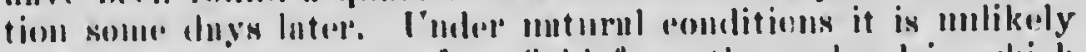

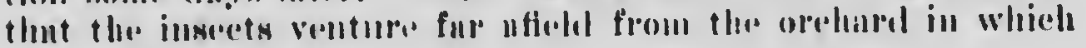
they have ilovelopmel.

In fereling, the molntt hoge will only hove resenrse to folingu when no other fool is IIviluble, evielently proferring a

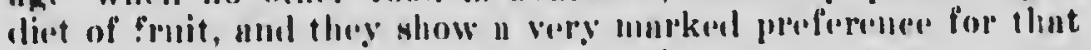

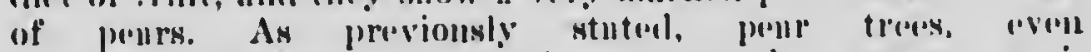
ill bally infesterl orehinris, commonly esenpe seri-

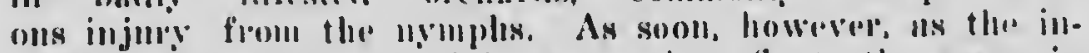

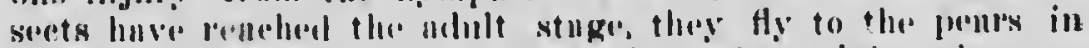

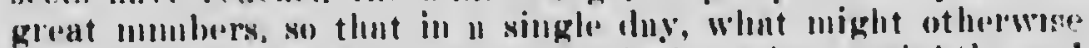

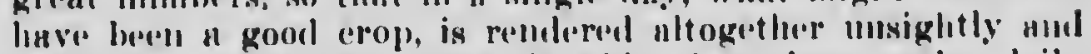

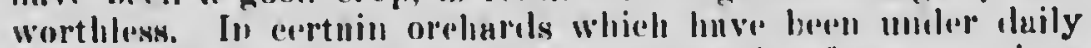
olservation, pears have been exmmineel bearing fow or no vions of injury, whiels on the suceseriing any would be fouml to be sur urumg with adnlt hogs nut hithed in sul oo\%ing from in-

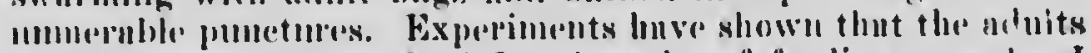
will fortake nll other food for the sake of fereling on 1 lard green pear. It mily thesefore he snicl thent while the daunge: to the mpple is moscly the work of the nymphs, the mujor purt of

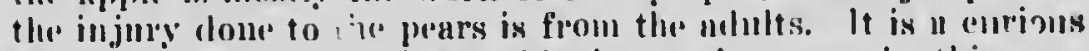

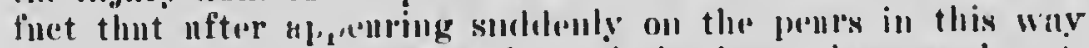
und foesling for a few alses, the mujority lenve them as mbrupt-

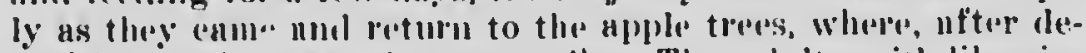
positing thrir eggs, thry soon die. The mohlts will liknvise

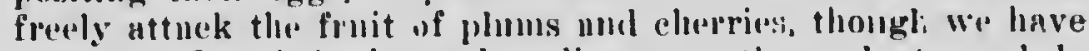
mever yet formel the insect brereling upon these plusts, mol do

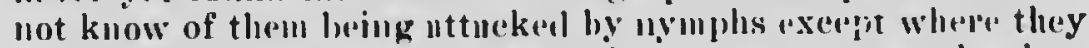

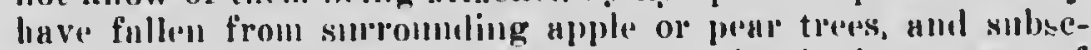

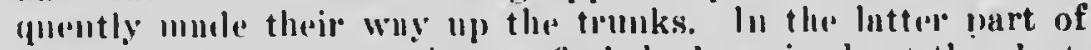
the smommer a common place to find the bugs is ubout the elnst-

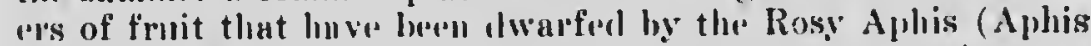

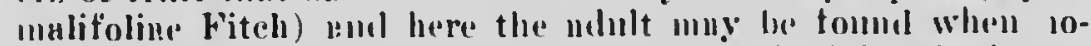
where else, late in the season. Such beluted indivionuls show a preferenes for overpipe or aven decuying fruit.

Like the nymphs, the arhits are frequently morlaceous in habit, the writer having been stumg on more than one oceasi in, 
Au athlt was oner observed with beak inserted in a full-grown tussock moth (Notolophns antiqua Limin.) larva, ancl only with diffienlty conlel it be indneed to relinquish its holel.

\section{CHARACTER AND EXTENT OF INJURY.}

\section{Injury to the apple.}

The first evillence of the insect 's injury is fomml upon the yoming and temler folinge in the form of purplisl spots upon the sirfiner. This symptom is very characteristic and makes it possible to detect the presence of the insect almost as soon as it appears, and long before it would be noticed by the ordinary observer". Twenty-fonl honl's after the insects liateh these spots are alrealy guite markecl. When the inseet is present in large numbers the leaves exhibit a tendency to enrl at the elges as a result of their work. As they anfolal and inerease in size the purplish cliseoloration gradnally clisappears. but if affected leaves are held to the light they will be seon to be piereed through and throngh with small holes, and in sever"o eases the loaf may present a very ragged and frayed appearnnee. By these symptoms the former presence of the bug upon the leaves may be detected. long after it has completed its t: ansformations and disappenterl.

The temcler, sn:enlent twigs of the enrent seasen's growth and even harder wood, is freely attacked, tle point of puneture being often marked by a dlop of elear or yellowish sap oozing throngh the bark. As the twig incerease; in size a ilecieled lnmu develops at this point, and in rapidly growing shoots; a longitulinal crack will sometimes appear. In heavily infesterd orchardis, where the inseret will be present in comntless thour-

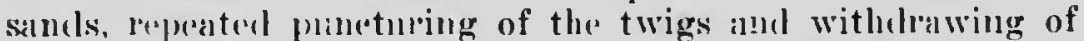
the silp ("anses them to wilt, the leares becoming brown and elry, and finally tla whole shoot dies. ('nises wherer a larege proportion of the twig: are literally stomg to death in this

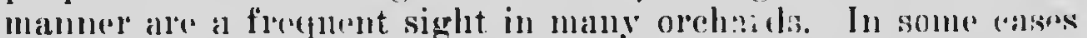
the continued killing of the young growth year after yealr we. sults in the death of even large limlss, and this, eombinesl wit! the work of vilricus womml parasites, may finally eanse the death of the tree. IImy casess have been observerl where bat-

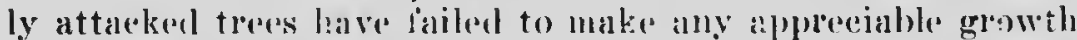
for a number of pears, so that it appeans to be only a question of time hefore sinch trees will die. The fluit spun's in these trees seem to be particularly injurionsly affeceted, so that a 
large proporticn of them nppear to be quite cily ant ilenth though others migl:t still be able to put fortl leave's mel blossoms. In contting into these spurs, the effeet of the intmm! erable punctures to which they have been sulnjeeted is at anese apparent.

It is interesting to note that once the inseets are destroned, these trees take on a new lease of life. "reses that haver been going back stealily for four or five years, when effiectively sprayed for the insect, immetiately began to senel out a strong new growth, and apparently lifeless fruit spurs have sent out shoots twelve inches long, or more. It would doulthless be some time before these trees return to normal and the fruiting wiond recovers from the injury it has received. Inteeet, in many rases it will be necessary for enew froliting wool to be formed before .a good erop can be expeeteet.

In orcharels where contitions are such that the trees are induced to malse a strong, vigorous growth the efferets of the insects injury upon the trees themselves may be longer in making itself apparent. Frequently in plaees where the crop has been entirely destroyed, and mueh of the growth killed, the trees are able to send out a strong, rapid new grewth, which, later in the season, completely conceals the injury that has been done.

As the blossom buds appealr they are quickly attacked by the young nymphs, ant these enteavor to force their way in between the blossom perlieels, npon whieh they feet. As soon as the blossom petals begin to operi, but before they have spreat apart, many of them work their way into the blossoms and eoneeal themse'ves anong the stamens, where they have been observed witl beak inserted directly in the pistil. ()thers have been obse? ved to sett!e lowil on the flowe of the blossom, and, inserting their beak in the leeceptacele, proceed to smek the juices of the plant. The tissue alout the puncture inmertiately

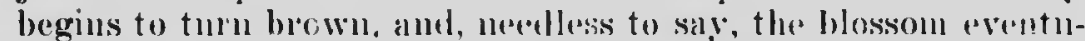
ally dies. When only inoterately attaci:eel the blossoms will usually drop to the gremul, but when pmotetured by many in.

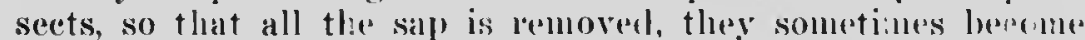
anite mumnified and remain elinging to the trees throughout the summere. Thuse facts explain why it is that batly attareknd

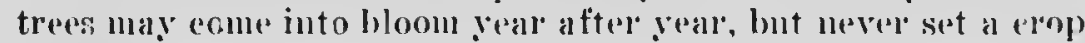
of fruit.

As soon as the frinit sets, dreps of sap, owzing thromgh the 
skin, show that if also has been punctured by the insect. A slightly raised discolored spot or pimple develops at the point of puncture, and the youmg apple soon drops to the gromul. Apples that are not attaclieel until a fair size, will usually remain on the aiese, but are batly gnaled or misshapen. The tissue about the puneture fails to develop, and as a result of the uneven growth the apple will be one-sicled, with a lionomeed depression at the spot where the beak of the ins:et has been inserted. The pumeture itself is marked by a brown eolky scar ancl ruptured epichermis.

\section{Injury to Fears.}

Pean trees are rarely attacked as badly as apples by the nymphis, but they are frequently lightly, and rarely badly i

fested. The injury to the leaves, stems and blossoms resembies that to the apple, except that in this case the ti we about the puncture turns black. The stinging of the yo f pers does not commonly cause them to drop to the extent it does with the young apples, but the effect of the punctures on the fruit is conspicuous. Injured pears levelop hard, corky, graumigl scars upon their surface, which may later split open, as in the case of the apple. Hard, flinty areas extend into the finlp, renclering such frnit quite unfit for use. Recent punctures are marlied by oozing sap, as in the case of apples.

Numbers of ole finit growers tell of having seell this $t$ ?pe $^{2}$ of injury many years ago. Year after year, early in .July, the pears would "leak" and later develop the elaracteristic seers. No one, however, as far as 1 am aware, suspecterl the peal culprit, or noticed the clamage clome to the apples. This is clue to the fact that the clicef clamage to the pears is done by alults, when the fruit is already well formeel, and conspicuous injuries are thus brought about, but the trees are not seriously affected. In the ease of apple trees, however, the greater injury is cione earlier in the season to blossons and very young fruit, which, as a consequenee, never develops. In mumelons instanees ninch of this injury is attributed to frost.

\section{Injury to Flum and Cherry.}

Injury to the frnit of plums from the alult lugs is net mucommon, where these trees are in proximity to infesten apples and pears. Plums injured by the bugs may be onk-sidne or misshapen, but the seat of injury is usually at the apex of the 
fruit, such injury being marked by the exulation of colorless gmm flowing out in the form of globules, or of a spiral coil, that finally hardens in the air. The injury clone to cherries is very similar.

\section{Injury to Quince and Rose.}

The injury to both rose and quince so closely resembles that done to the apple that a separate deseription is unnecesssary.

\section{FEEDING EXPERIMENTS.}

In infested oreharels lecre mmmbers of nymphs are fiequently shateen to the ground by sprays, heavy rains, wind, ete, and many drop with injured blossons or fruit as it falls to the gromil. In numerous instances such bugs have been observed feeding npon dandelions (Taraxaeum officinala), couch grass (Agropyrum repens), red clover (Trifolium iratens(') and various other plants growing at the base of the tree. Thongh we were able in no ease to rear the insect from the egg to the alult stage upon these plants, nymphs of the third, fourth and fifth stages readily underwent the remaindor of their growth upon varions plants offered to them.

In 1915 a number of nymphs in their third, fourth and fifth instars were divided into lots of ten and placed npon "arions plants growing in the insectary. Some of ach lot snceededed in resering maturity, and the following observations as to their areet npon the plants were male:

Grape (Vitis vinifera). - The nymples feed quite reaclily upon the grape, leaves, stems and blossom elusters being soverely pumcturesl.

Elm (['lums antericana).-The injury to the folinge of the elon was notiecable in dark colored spots or blotehes, but th re was little or no twig injury.

Sugar Maple (Acer saceharum),-Injury to maple leaves was slight, apperaring as small transherent spots. The insect dicl not feed reaclily upon this plant.

Sweet Cherry (Promus avimm).-A slight pmetnring of the leaves and blossoms and gimmony exnclations from the firuit, lnit injury not prononnced. 
Feach (Prumus persica).--I.eaves showed plainly the wi. et of the iusects punctures, und small globules of transpar nt gum issued from injured fint.

Strawberry (Flagaria virginiana).-Strawherples showed evidence of considelenble iniury: hlossoms and leaves were so. badly punctureal that they finaliy withered and died.

Couch Grass ( $A$ gropyrum repens)-The iujury to theblacles of concli giass wals marked, the plants becoming notice. ably wilted and faded in color.

Dock (Rumex erispus). - Ferl reatily on the plant, pusectiring leaves and fruit.

In the spring of 1916, 25 plants, common in and about oreharils. were planted in pos in the gerenhonse, and on each. were p!aceil five secomd and third stage nymuhs, with the following results :

Plant.

No. Keaching Maturity:

Chickweed (Stellaria media)................. 2

Rose (Rosa rugosa)........................ 1

Sw n: Briar (Rosa rubiginosa)................. 2

Cultivated Sirawberry (Fragaria virginiana)...... 4

Wild Strawterry (Fragaria chiloensis) ............ 2 .

Buttercup (Ranunculus acris) ................ 0

Dancelion (Taraxacum officinale)............. 1

Golicn Rod (Solidago gramimfolia)............. 0 ,

Golden Ro: (Solicago graminifolia).............. 0 .

Broalleaf Plantain (Plantago major)............. 3

Narrowleal Pianta:n (Plantago lanceolata).......... 2:

Couch Grass (Agropyrum repens).............. 3

Daisy (Chrysanthenum leucanthemum).......... 1

Mulic:n (Verbascun thapsus) ................. 0

Yarrow (Achillea miliefolium) $\ldots \ldots \ldots \ldots \ldots \ldots \ldots$.

Raspberry (Rubus strigosus)............... 3

Vioiet (Viola cucullata)...................... 0 .

o:chard Grass (Dactylis giomerata)............ 3

Shcep Sorrel (Rumex acetosella).............. 2 .

Alsike Clover (Trifolium hybriduni)............ 4

Re:-top (Agrostis alba).......................

Dock (Rumex crispus)...................... 2

Fall Dandelion (Lcontrion autumnalis)........... 0

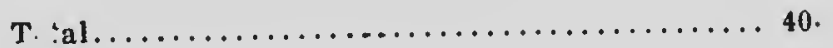


We see from the foregoing that out of a tatal of one limelred and twenty-five, forty nymphs, or $.32 \%$ reached maturity. This is 110 index, howevil. of the number that might eome through nuther natural con- ditions, sinee the rearing of the iusect, even on its natural fool plants, is a matter of ensiderable diffieulty, and aecompanierl by a high mortality. Furthermore the weather at the time was - extremely damp, and moistmic collected fremly on the sioles of lamp elimmeys that were used to cover the plants.

\section{THE GREEN AFFLE BUG AND EUROPEAN CANKER \\ (Nectria ditissima).}

The European eankel is very eommon in the orehards of Nova Seotia, working large'y in the larger limbs, frequently eausing theil cleath. It appears that the clamage form this - disease is largely incerensed by the presenee of large numbers of the green apple bug. In smelt eases it was bosn fomml that an mulne amomnt of this disease is present it aller limbs and twigs. The puneturing of the wool by the be " of the inseet affords lodgement for the spores of the fungus, so that the life of many trees is aetually menaeed by the eombination of these two pests. New eankers are eommonly seen developing about the spot where the skin has been pierced by the inseet.

Thongh the evidence that eommets this inseet with the disease is only eireumstantial, it is suffieiently strong to indieate that the presenee of this bug is an important factor in aggravating the damage done by this disease and in promoting its spread in the orehard.

That many inseets are aetive earriers of varions plant aiseases has been demoustrated experimentally by various workers within reeent years. Gloyer and Fulton lave reecintly shown that tree criekets (Oeeanthus spp.) aet as earriers of the fungus, Leptosphaeria eoniothyreum, from laspberry eanes to apple trees. In the same publieation these writers also give a sliort raview of the 'iterature on the transmission of plant - diseases by insects.

\footnotetext{
Gloyer, W. O. \& Fulton, B. B., Tree Crickets as carriers of Leptosph:teria coniothyreum Sacc. and other Fungi. Tech. Bull. No. 50, N. Y. Agr. (EX). sia. (1916).
} 
The relation between the Lyzus and Nectria is probably more inclirect than the case just referred to. It is possible that some of the spores of the fungus may actually ching to the body of the inseet, but its chief role cousists in furuishing an opening for the entrance of the summer spores, which are produced abundantly throughout the season, particularly in damp weather.

\section{THF GREEN APPLE BUG AND FIRE BLIGHT (Bacillus: amylovorus).}

The withering of blossoms and leaves accompanying the attueks of this pest were so strongly eharacteristie of fire blight that at first these symptoms were aseribed largely to this disease, and the bugs regarded as earriers. This is only what might be expeeted, since this correlation between the prevalenee of fire blight and the presence of sueking insects has often been observed. Typical specimens of injured blosinm elusters and twigs were aecordingly subunitted to leading ant. thorities in the United States and Canada and the trouble diagnosed as fire blight. It soon began to appear, howerer, that the bug alone was responsible for much of the claninge that has been attributed to the clisease. In all our work throughout the Valley we never saw any signs of the blight except where the insect was present in large numbers, and its severity varied directly with the degrec of insect infestation. Every blighted twig or shoot showed unmistakable signs of having been punctured by the insect. Only very rarely was the disease founcl to be running back into the previous year's growth, and in spite of a careful search, few so-called "holdover" eankers could be found. It was found that new shoots generally arise from beneath the injured spur or twig, and the injured growth esmmonly, but not invariably, falls off before: the end of the season. Furthermorc, orchards that have suffirred from the blight for years, show no signs of it when the inseets are destroyed by spraying. We could always produce a blighted appearance on apple twigs by allowing a number of bugs to feed on them and; as similar symptoms have been observed to follow the attacks of aphids reared from the egg state in the laboratory, it would seem difficult, in many cases, to distinguish between the damage done by the disease and that duc directly to insect punctures.

Spccimens were accordingly submitted to Prof. V. 13. 
Stewart, Dept. of Plant Pathologa, ('omell l'uiversity, who has recently macle a special stmily of the problem of ine bliglit transmission by sneking inseets. P'rof stewet expressed the opinion that while a lomber of the twigs were momistal:ably affeceted with fire blight, a large anomint of the illjury was eansed by the insect alome. It would thus uppeat that, while it is often impossible by a smperfieial examination,

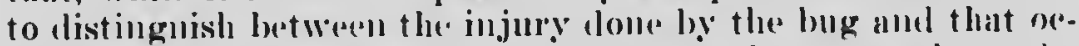
easiomed hy the eliseass, particularly in ohl trees whele the blight aloes not extemel ciow the trees for any gleat distrues. it is not really necessary, from " practieal stamelpoint, that

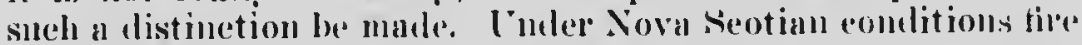
blight on apples has not pet shown itself to lo a sements diserise. As fur as ontrobservations go, it is only with the presence of the insect, moler favorable eomlitions, that it is able to make any progeress, ant onee the inseets ale lestroyel injury from this somer cerses. ('utting ont the disensed woot, as is commonly done for file blight, woulel ore nseless in wellmols infested by the gleen apple bug, where the mationel:al twigs woulel soon be reinoculated by the my rials of insects ther swarlu over the tree. For all prictical purposes, therefore. the fruit-grower ean regard the bug as teselving of first consuleration, and onee that is destroyed he will probuhly fimd that the disease has disappeareal also.

\section{SUSCEFTIBILITY OF VARIETIFS.}

All those who have had the misfortume to have had an infestation of this pest in their apple orchinels, agree that the Nonpareil (Roxbur! Russet) suffers most. The infestation is invariably notieed first on these trees, and the bugs are ahosest invariably most mumerous on this variety, though the Fullawaler sometimes comes a close second. No variety, however, is altogetleer immmone, and the common experience is that it will gralually "mlarge its fielel of opelations from the more to the less susceptible valieties. Ribstons and Golden Russets frequently sutfer severely, while Gravensteins, Blemheins, Baidwins, and Greenings are also reportecl as being among the susceptible sorts. Onere, howerer, the pest has become tirmly established it is only a question of time before all otler valinties are attacked.

Anong pears, those of the Bartlett variety seem to suffer most severely. In fact, it has been believed in sone sections that this trouble is a disease of the Bartlett pear, but observa- 


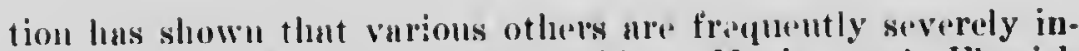
jurel. ('lappis Fuvorite, Burluridge, Maria, and Flemish Benuty may be included among the susereptible varieties.

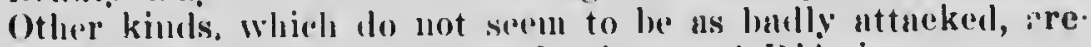

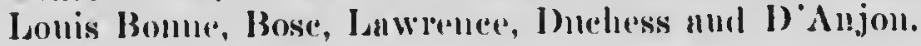

\section{CONDITIONS FATORING INCREASE.}

It is alficult to state definitoly muler what romelitious the inseret Honrishes best, since it is fonmel in orehurels that have

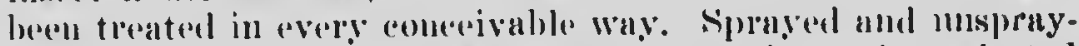

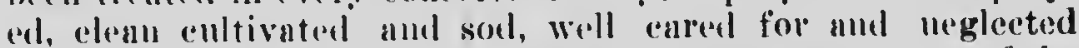
opelands are all attacked. It is a notalole fact that many of the worst infestutions ure in orelindels that have reecived the very

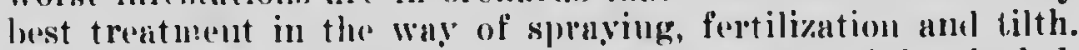

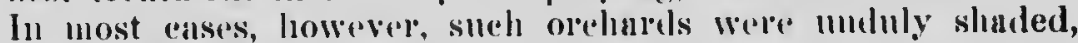
being insufficiently promed, too thickly planted, or loth. Some of the olelateds which lave suffered worst have been enltivated on the strip systen, i. P., with a strip of elover or gruss alterlating with a clean enltivated strip. lu fact, a very large propoltion of the worst infestations were found where there was a eertain anomit of growtl at the base of the tree reither in the way of sol or werels. 'This may be due to the fact that in

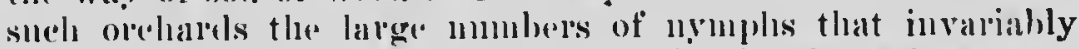
llop to the groutud are liable to maintain themselves upon these plants and so leach maturity, whereas, mulep a rigid system of elean entivation, many would he malsle to reach

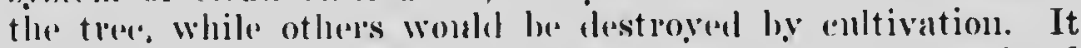
was also noticed that in low-lving genome or where the olechard was selerenerl from the wind, theere the infestation was likely to low most severe.

As a lessult of axtensive olservations throughont the infestrel andea, it apperas that the most snitable comelitions for the mulue incerease of this pest ale shaty oreharels witlo elosely planted. thickly growing trees. With poor air chainage. and a certain antomut of herbage growing mpon the grounl. Healtiy, vigolons trees. making an excellent growth, fieculuently suffer most, and, intil woakened hy lepeated attacks, will pit forth a heary socounlary growth to replace that elestroyed by the bug. These foregoing factors are not, howerere essential to a destructive onthleak, as the insect is capable of loing injury Intelep a wide range of conditions. All the folegoing refers to apple oreliards alone, though the same holels good, to a certaitr 
PLATE II.

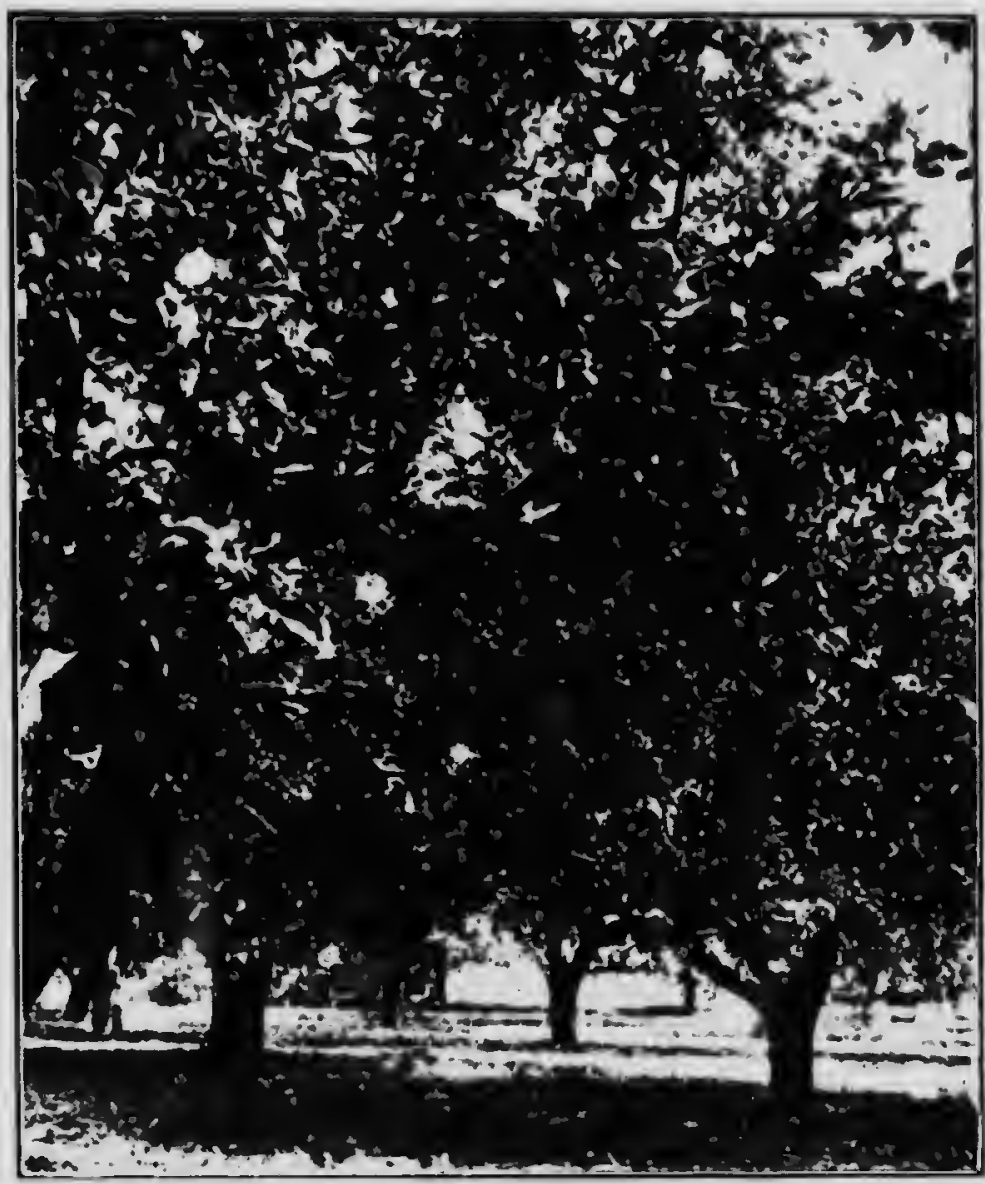

An orchard in which the bug has destroyed the crop for a number of years past. (Original.) 


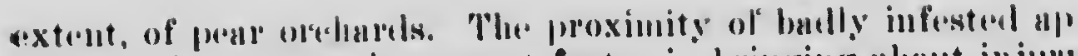
ple troes is the most importunt futer in loringing ubout in.in? to the mists.

\section{NATURAL FNEMIES.}

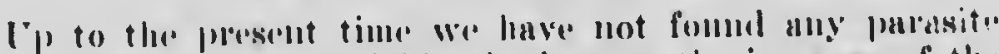

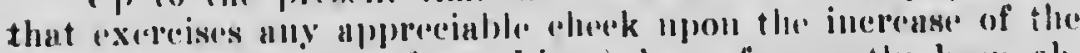

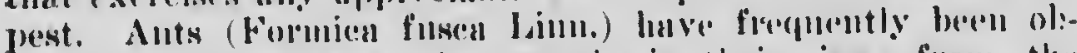

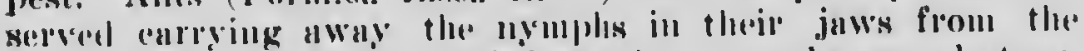

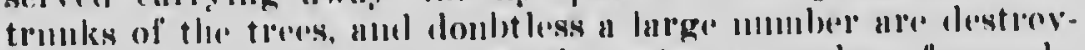

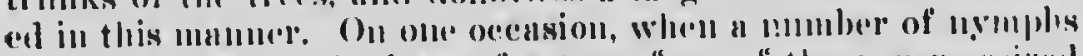

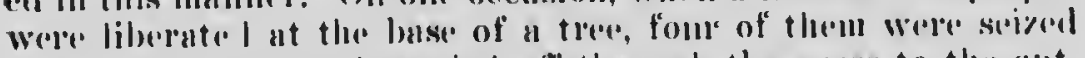

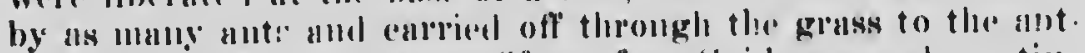

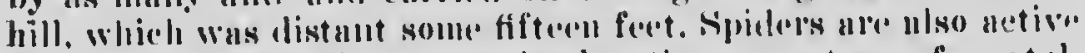

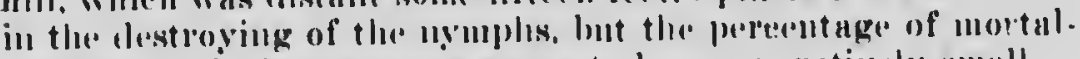
ity from both these someres serems to be comporatively small.

\section{CLASEIFICATION.}

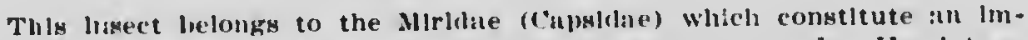
portant fumlly belonslng to the sub-orler Heteroltern, order Hemlitorit. Thls famlly is largely repreqented in our fauta and contilus msiny fornis injurlous to plants. and others that are firediceous In 1. 1,it.

The specles hereln dlscussed has heen general!y confused with related forms. Firller workers doubtless mistook it for the conmon ldigus I rittensls, whlle of recent years it has generally hee: referred to as $1 . y^{2}$ "ls Invitus say. Recently it has heen lescribed as l,ygus communis II. sp. ly hnlght (lt). Int the Nova scotlan form as a new varlety miler the name novaseotlensly (15). Accormlngly, the full mame of the Insect is I,ygus communls var. novascotensis Knlght. losicte and Horlgklss have proposed the name of False Tarnlshed l'lant Bug for the typleal communls. but the Nova sicotlan varlety is now well known in the urovluce as the green aluple bug, or simply" as the "green luug."

\section{DESCRIPTION OF LIFE STAGES.}

EGG.-The egg is smooth and cyllndrleal, but curving sllghtl: towids one side: constricted near broatened and flatened apex into hroal lierk, about whlch is a narrow collar, somewhat wliter than the neck: bise rouncled, margins at centre sllghtly swollen. Chorlon, dellcate, coarnaly punctured, trangluctent. Collar, whitlsh opaque. Cap, coarsely munctured. General color, pale yellowlsh white, translucent. Length, $.752 \mathrm{~mm} .-835 \mathrm{nt} \mathrm{n}$. Wildth, $.195 \mathrm{~m}$. $1 .-.221 \mathrm{~mm}$.

Nymph,-The nymphs resemble each other closely in general form, the first two nymphal ingtars being palr yellow in color and the last three sroen, with more or less yellow about the head and thorax. In the last two nymphal linstars the wing parls are plainly vlsible. 
FIAST INSTAR.-Boly long, nurrow: laternl margina nurrowent de caublal margin of prothorax. thence wilening very wikhtly to chuilat margin of metathorax, and uguin to Jroalest purts at thirl alolominul negment. Head, more or lesm trlatuxular, liroully roundell ut apex. Prothorax, one-nixtit fonger than beal and of equal wlith, exeludling ejes; Mesothorax, of mame leoktl ux the head, wlightly broaler than prothorax. Abdomen, pyriforin, Lintire dormal. ace covered with stout lark huirs regularly placel, and nner halrs irregulirly placed, theme hulrm, llke those on the femorn, beine three or four lirunehed at the tip.

Antennae, medlum lenkth, stout, pulsescent, with terminul megment more thlekly covered with eosirmer hulrm. Jength $\bullet$, sis $\mathrm{mm}$., Int wekment, .113 min. : 2ul sekment, .21 $\mathrm{mm}$.; $3 \mathrm{ral}$ мeкnent, .217 $\mathrm{mm}$.; th meginent, .327 mm.

Lege, fonk. fuiriy mtolit, clothel with fine hatre r. tlbla unit tarsus, Stout hatirs on femorit. length of hind thbla, .50 nin.

Color, whitish to pale yeliow, rurely hrixlit yellow: brikht orange yellow

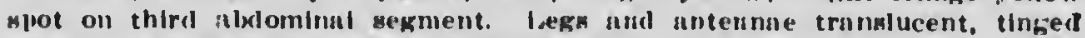
allohtly with kreentah yellow. Fyes brikht red.

Length of Body, .\$57 mm.-1.15s $\mathrm{mm}$. : wlilth, .305 $\mathrm{mm} .-.407 \mathrm{~mm}$.

EECOND INSTAR.-Bods, broaler anl stouter than preceling Instar,

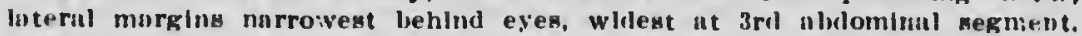
Head, triankular, rounded hefore eyem. A few stout hairs placel rekilariy on cephalle markin anil front. Prothorax, broul, equal in langth to fiend. narrower at eephulle murgin. Mesothorax, loronder and ahorter than prothorax. Metathorax, very stightiy morter anul broader than mesotiorax.

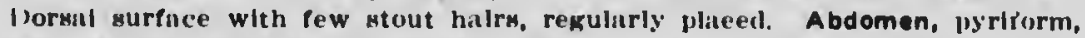
bearlng boly hatrs as or henti and thorax.

Antennae, more flender tlian in preceling Instar: clothel with line hairs, ewpeclalis on tf rninal segment. Jength, $1.18 \mathrm{~mm}$; Ist segment, .137 mm.: 2nd segment, .35 mm.; 3ril segment, $3 \mathrm{~mm}$; 4th segment, .395 $\mathrm{mil}$.

Legs, more slender than in precellng instar: femur bearing few tong. stout huirs: thia und tarmus elothel with fine hairs, particularly the d!stal extremity of the tibla. Length of hind tibla $.75 \mathrm{~mm}$.

Color, inht greenish yellow, ingesta slowing dark greenish though ablominal wall: usual orange spot on third ablominal aegment. byes dull red: legs and antennne of a duller and lighter vellow than the horly.

Lenoth of Body, 1.2s $\mathrm{mm},-1.375 \mathrm{~mm}$ : widh, .413 $\mathrm{mm},-.557 \mathrm{~mm}$.

THIRD NSTAR.-Borly long, hroad, flattened, lateral murging narrowest behind eyes, thence dlverging somewhat sharbly to 3 rd aldominal seginent, thenee tapering grallually to eaurlal extremity. Head, similar to pieeeding Instar. Prothorax, equal in leugth ubd sltghtly hroatler than heul, w'dentug towarls eaudal border; caudat margin sllghtly procurverl. Mesothuiax, one-half length of the prothoricx, one-fith broacler. Metathorax, one-thirl shorter thin mesothorax, very sllghtly broaler. Caudal inargin procurved. Mesothorax and metathorax projecting very slightly eaudal at lateral angles. Abdomen, broad, flattened, flrst seven segments marginate. Entire dorsal surface covered with short, lark halrs, thinis and evenly placed, but relatively smaller than in preceding instars.

- The antennal measurements given are averages from several |7qfis. There is considerable varlation. 


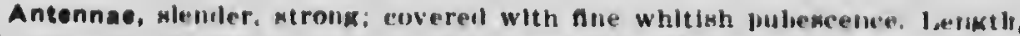

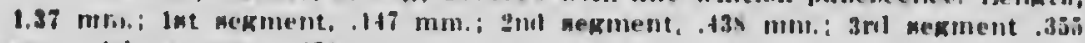
$\mathrm{mm}$.; th nekment, . $130 \mathrm{~mm}$.

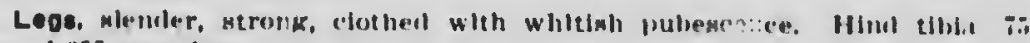
$\mathrm{mm},-1.037 \mathrm{~mm}$, lonk.

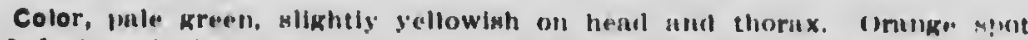

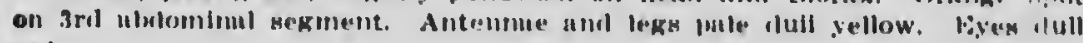
real.

Length of Body, 1.5n-2.29mm.: Wilith, .il: mm,-..913 $\mathrm{mm}$.

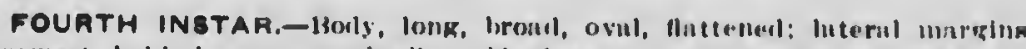

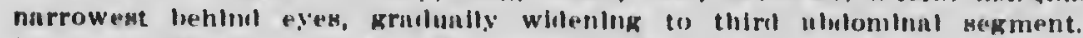
Head, triankulur, rounlwol. Prothorax, liroul, lut marrower thun inall: equal to heal in lonkth: lateral markin mikhtiy dlverkent: litemil anklion af mesothorax and metuthorix frojecting culululis, formlug small whis buls, renchling ulnowt or "fuite to thiri ablominul sekmsut. Abdomen, iroatl, Anttelled, Jyriform. Dorsul surfice smooth.

Antennae, lonk uml wenler. Iength 2.73 min.: ist wegment, .3t inm.: 2nd aerment. .936 mm.; 3ril xesment, .708 mm.: th wesment, . Ann

Legs. Jonk und menter; hind this $1.4 \mathrm{k}-1.6 \mathrm{~mm}$, Jonk.

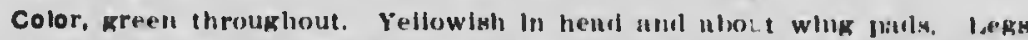

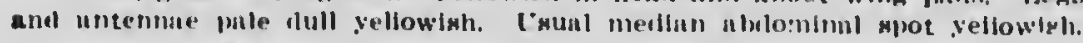

Length of Body, 2.75 mm,-2.97 mul.: wlilth, $1.107 \mathrm{~mm},-1.16 \mathrm{~mm}$.

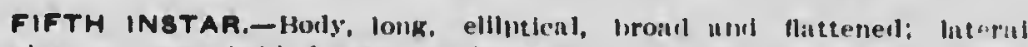
marking nurrowent hehiwl eyes, curving genty to ciluilil murain, the wident part helng Just half the lenkth of the holly. Head, in in frevious stigun, but relatlvely smulier. Prothorax, equal in length to heal: anterlor miskins diverxcit ciulally. Mesothorax, one-wixth sioter than prothorix. Metathorax, one-fourth length of $m$ sot" extendinx almont to cuubal murgin of foui,liblonibul segment. Abdomen, pyriform, slightly markimute. I torsal surface smooth.

Antennae, long strong. length. $3.42 \mathrm{~mm}$.: 1 wt нegment, $3 \times 7$ min.: ?ul segment, $1.267 \mathrm{~mm}$ : $3 \mathrm{r}$ l segment, .9si mn.: 4 th segment, $733 \mathrm{~mm}$.

Legs, ntronk, clothed with hairs as in precellng instars. Hind tIbia. $\$ 45$ nim.

Color, pale green: npex of heal, marklns of whgs und marglu of thorax yellow: shortly hefore moulting the wing latls hecome dark hrown it the tlys. byes areenish white, lut seen under the microscope the infiridual facets illueir reclilish brown at their centres.

Length of Body, i mm. $-4.2 \mathrm{~mm}$.; willh, 1.62-1.55 mm.

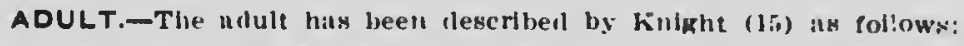

"Lygue communis var. novascotiensle $n$. var. l'aler and inore H miler than the typlut communis, but not ilfering materially in the male clasiers. Breeds abundanty on allple in Nova Scotla; but in New York 1 have been unuble to take any form of communls on the apple.

length, $5.3 \mathrm{~mm}$.: greatest wilth $2 \mathrm{~mm}$.: more slender anul much paler than the tyllcal conmunis: the two black rays on the pronotum small but distinct: hemelytra more yellowish brown than fuscous: lateral utripe of the body redellsh or darkened with fuscous.

Thls is one of the varietles or races of cominunis which may be worked out fron the forms inhabiting different plants, and perhaps influelined somewhat by different external conditlons." 


\section{METHODS OF CONTROL.}

\section{Bpraying Experiments in 1916.}

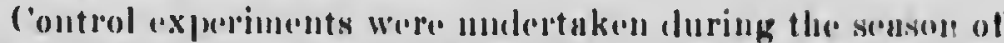
1915, though mulcre most unfuvoruble conditions, the wintlucer being ulmost contimunsly wet. This macle it alifficult to upply

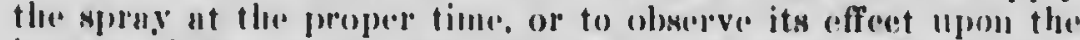

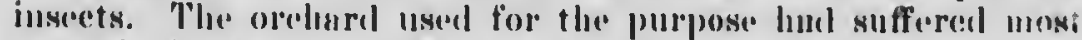

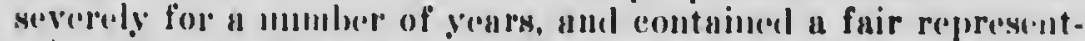
ution of the labling varicties of upplex and pestrs, most of which wore scroroly uttueked.

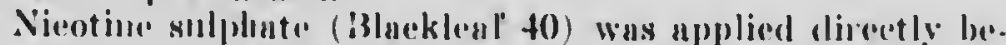
fore and directly after the bloom, adding it to the regular lime

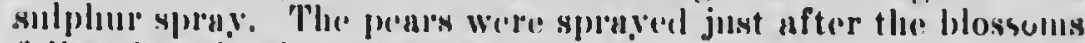
foll and aguin about a work later.

At first the affeet of the spruys soremend to be :intisfuetory, but subsequent exaninution slowed snfficiont bugs pursont to alestroy practically the ("ntire cerop). As large nmmbers of (lend longs conlel be soen adlacring to the legves, and us all laborutory "xperiments showed that the material ouployed was coffective in killing the insoet when hit by the sp) 'ny, even when in mueh Wonkere strongtlis than that lised in the field, we were nt first. muble to aceount for this fuet. It was soon aliscoverol, iow"vor, that large IIImbers of nymples wore continually ascending the tree trunks from the gromel, mul subsequent investiontion revealed the faet that aven in minsprayed oreliarcls large

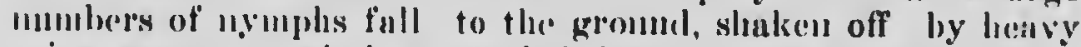
mins. sprnes or wiml, or enreried down by the dropping of injured blossoms or frut. In many ordhards that lial not berall

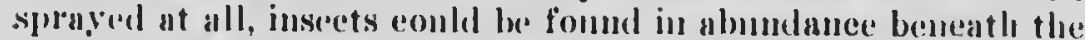
treess and aseending the trunks.

\section{Climbing of Trees by the Nymphs.}

In order to determine to whint axtent nymphs were wasl! al off during spruving. und whethe: any considerable portion

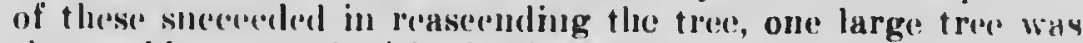
thouponghly sprayed with nieotinc sulphate and soap, after h:1sing becon banded with tree tanglefoot. Shortly after spraving the trunk of the tree bencatlo the band was swarming witli the myuphs. These as a rule dicl not rttempt to get ovor the busd, and only a small mmber wore setua!ly eanght therein. 'J'he bugs bencith the band wore romoved and eounted each day for seven duys, the total mmber taken anomnting to 1889 . Linge 
numbers also went up aljacent trees, 538 being taken from on:of these, while many others could be seen feeding on the valions grasses ancl weeds which weres abundant in the oreharel. It should be noted here, that these mmbers lepresent but a $\because$ iry small proportion of the insecets originally present on the treer, the deacl bodies of which could be fomme in abmulance sticking to the leaves or stremin upon the grouml. Nevertheless, owing to the vast number of insects present and their tenelency to serek out and feed upon the fruit, sufficient escaped to render the spraying futile.

It is only in the last three nymphal stages that the insect. can readily make its way over the gromel and reach the trees. Fin'st and second instars are likely to become engulfed in the small openings in the soil, anel so perish. Moreover, the young nymphs do not fall to the gromel as realily as they do in the later stages.

\section{Mechanical Effect of the Spray.}

To cletermine whether the effect of the spray was merely mechanieal, ancl whether or not it might be possible to control the insect by a heavy spray of water alone, another badly infested tree was given a strong spray of water, using a Fienel "drive" nozzle and a pressure of $200 \mathrm{lbs}$. In this case the total count over several days amomted to 308 , and an "xamination of the tree showed that there was no appreciable dimintion in the number of insects present. This showed conclusive!y that the insects do not drop to the gromel with sufficient readiness to allable us noticeably to rednce their number simply by forcing them from the trees by a strong spray. It also shnived that there was something besicles mere meclianical affect respousible for the large (lrop from the tree sprayed with nirotine sulphate. The insects at this time were in their last ny.nphal stage, and it may be that many of them were only partially covered with the spray, and accordingly only temporarily owalcome. It is possible that the effect of the nieotine fumes is to make the insect relux its hold and lrop to the ground. Some experiments conducted last season seem to inclieate that lhe fumes of the nicotine sulphate wero themselves deadly to the insect, but later experiments molertaken on a large scale disprovel this. In any case it is always true that a large number of nymphs fall to the ground, ant of these a considerable proportion again make their way up the tree. The larger the nymphs the more readily does this dropping oceur, and the sooner the spraying is done after they latch, the smaller the 
numbers that will be fomed making their way up the tres. It is obvious, from the foregoing faets, that in order to (ontron this pest solecessfully, something must be done to prevent the reaserent of nymphs whieh have fallen to the groumd.

\section{Distance Travelled Over the Ground by Nymphs.}

Experiments ware molertaken to determine the distillee

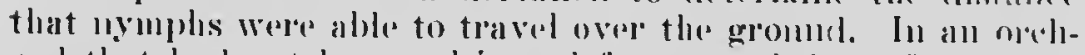
ard that had not beene enttivated for several days, four trees. $30 \mathrm{ft}$ apart each way, wrere banded with trees tanglefoot and

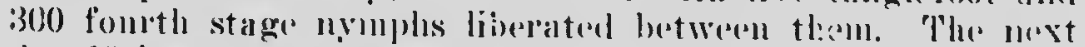
day 19 insects were taken from benesth the baseds. A similar

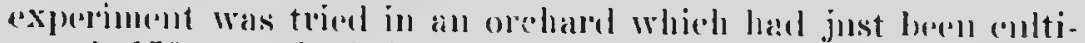
vated, 150 mymples being employed. In this case 17 insecets reached the tree. This experiment was reperated in a sod

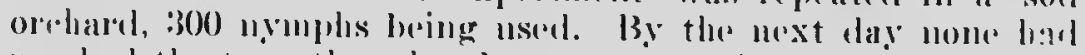
reached the tree, thongh subsequent ixperimeats and observations have shown that they are (apable of making their irat over sod groumd for eren grreater distances. The tendeney in

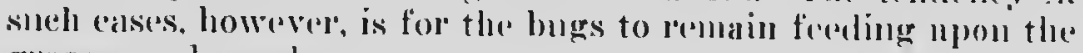
giasses and wronls.

\section{Spraying in Conjunction with Band:ng.}

Thongh at the time when the foregoing facts were discovred it was too late to save the erop, sinee the blossoms w. re already irreparably injured, it wass deteromined to test the effect of banding the trees with tanglefoot before spraying. A bally infe'sterl block was accordingly pieked ont, some of whicd were banded, others left mbanded as cheeks. $A$ heary derenchspray of nicotine sulphate was mext applied to all the troes. An examination the following day pevented large numbers of longs present benenth the bands, but fiew or none contl be de. teeted on the banded trees. On the anbanded trees, howerer. there was a stady strean of nymplis aseending the trunks, so that in the eourse of a few days they could be found in all parts of these trees.

\section{Spraying in Conjunction With Cultivation.}

Other trees were sprayed and the gromnd beneath them inmediately given a thorough harrowing. It was fommel that this gave practically the sane results as banding, so that if an extra team were available to follow behind the spray maenine banding would not be necessary. 
It was also fomml that whethere bunded or not, the orelariel must be cultivated, snbsequent to spraying, in order to destrey the vereds and grass at the base of the trees, as the nymphs ale capable of completing their development mpon such plants. ('ases have heren noted where the good effects trom splraving

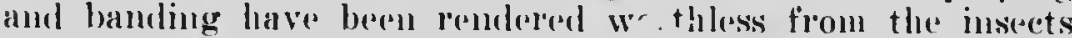
Hying "1) and attacking the frnit anc ovipositing in the twigs, after having come to maturity on werels growing in the oreble arcl. This was fommel to be particularly true of pears, which are espereially attractive to the adult inscets. A low of lartlett prans, growing in sod, was eleaned of the insects by cale. fully splaying and banding. As soon, howevere, as the adnlts apperared there flew to the pears in large mumbers, as many as 18 being fomml on a single small frolit. In this case, many of the bugs cante from nearby apple trees, but mumbers of them were those that had eompleted their development on the grase and words.

\section{Lessons Learned from 1915 Experiments.}

The work of 1915, while failing to control the inserets n the orchards treated, before they had practically completed their clannge, pointed plainly to the mothods which must be alopted to attain suecess. It showed elenrly that the pest was a most difficult one to control, and that a very thorough spesying onee before and once after the blossoms womld have to be applied in order to destroy as many of the mymples as possibles. It tanglit ns that it was next to impossible effectively to spray thickly growing, ol very high trees, and that a good proming shomld be a necessary preliminary to any attempt to radisate the pest in the oreharel. Furtlermore, it was shown that trees innst be banded with tree tanglefoot bofores spraving, of ase coltivated immodiatoly afterwards. to prevent the ascent of bugs from the gromul, at least in eases of sevele infestation. Lastly, it inclieaterl that such orelands most be kept in a state of elean enltivation mitil all the insects have reached the alult stage.

\section{SFRAYING EXFERIMENTS IN 1916.}

Witl the foregoing facts before us, we were able in 1316 , to proceed intelligently with the control of the pest. Two of the worst infested orehards of molerate size to be folmel in the Amlapolis Valley were chosen for this purpose. 
Orchard No. 1.-This is a fonr aere block and situated at Hortonville, Kings Co. It was at one time a heavy bearer, but the erop lass been rapidly falling off of late years. The injury to the pears has been long noticed, but the injury to the apple was not deteeted intil about five years ago, when it was notieed in a Nonpareil tree in a eorner of the orehard. In 1911 the few Nonpareil trees in the orehard bore thirty-eight barrels of npples, the next eight, and sinee then none at all. Not only was the erop destroyed, but the trees themselves have been very serionsly injured, the limbs being covered with fruit spurs whieh were to all appearances deatl, as a result of the inseet's work. Even though the pest is kept down in sueeceding seasons, it will be some time before these trees lave reeovered from the damage that has been eansed them. Though the damage to other varieties was not so great, the Gravensteins, Rnssets, Baldwins, Ribstons, ete., had also suffered to a considerable degree, the trees being weakened and the erop destroyed to a greater or
less extent.

The trees were pruncel as mueh as was eonsidered safe, and, where neeessary, were leaded baek to faeilitate the aetion of the spray; the trees were banded with tree tanglefoot and the orehard enltivated at intervals until the end of the first week in Jnly. Careful cxamination of the trees showed the bugs to be present in large numbers, as many as twenty- wc having been taken from a single blossom ehster while twelve or thirteen were common, and five or six the general rule.

The first spray was commenced when the Gravensteins were just begiming to open, using nieotine sulphate (Blaekleaf 40) 1 pt. to 100 gals. of regular smmmer lime sulphur spray. The early varieties wele sprayed first, our ain being to treat each variety just as late as possible before it eame into bloom. A Friend "drive" nozzle was nsed throughont, and the most thorough work possible was done. This task was rendered mueh simpler by the pruning which the trees had previcusly

Towards the end of the first spray the bugs began to fall from the tree in inereasing numbers and to eluster beneath the tanglefoot bands. Only a few, however, aetually became entangled in them, as most of them, after wandering over the base of the trees for a few hours, left it for nearby weeds, where they were later destroyed by enltivation. The application of the seeond spray was commeneed when about four-fifths of the 
blosson petals had fallen to the gromel. The same materials were used exeept that Hour paste was atded as a spreatele no a portion of the orehard.

Orchard No. 2.-This is a six aere oreharel located at Clarence, Ammapolis ('o., ant like the other was formerly a heavy bearer, but, though only the crop of the Nonpareils had been completely destroyed, the pereentage of No. 3 's and enlls on the other varieties, had been growing rapielly. There alre s.o Nonpareil trees in this oreharel. which in 1911. the first yeill of

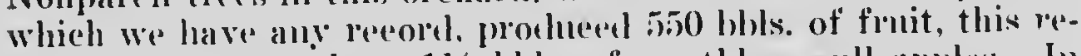
dueed in 1915 to about $1 \frac{1}{2}$ bhls. of worthless cull apples. In that year, aceoreling to the owner's statement, "the horso ate the entire crop of Yompareils." 'illongh the owner has heren able by gool treatment to mainain the erop on the other varieties more nearly at ahe same level than in the case of the Nonpareils, a large percentage of th 11 are so misshapen as to be entirely worthless. The mumber of 33 's and entls has steadigy, with some variation, increaseel fron:s $+0 \%$ in 1911 to $86 \%$ in 1915. Though factors othen than the bug were in ?alt responsible for the produetion of 3 's and culls, their steatly increase ean be largely attributed to this somree. These figmes do not, of course, take any account of the loss in vigor wetersioned the infested trees lye the work of the insect, which. "ven with the best of treatment, will take some grears to restore. The damage done to the trees in this oreharel was most noticeable in the Nonpareils, as in orehard No. 1. Nevertheless the damage done to other varieties was rapilly inereasing.

The spraying in this orchard was lone on the same plan as in orehart No. 1, except that soluble sulphur was used in the secont bug spiar, and the nicotine solution added to this compouncl. A soft tish-oil soap was adeled to a portion of this spryy to act as a spreater. For this reason we alded no arsenieal: but, as the bud moth and other biting inseets had been controlled by previous sprays, and ar ate codling moth is not a serions pest in the loeality, we were quite safe in thoing this.

After the first four days of spraying the bugs began to drop from the trees in large numbers, seven hundred being taken from the base of one which was badly infested. These, however, som left the tree for the weeds, where later the cultivator destroyed them. 


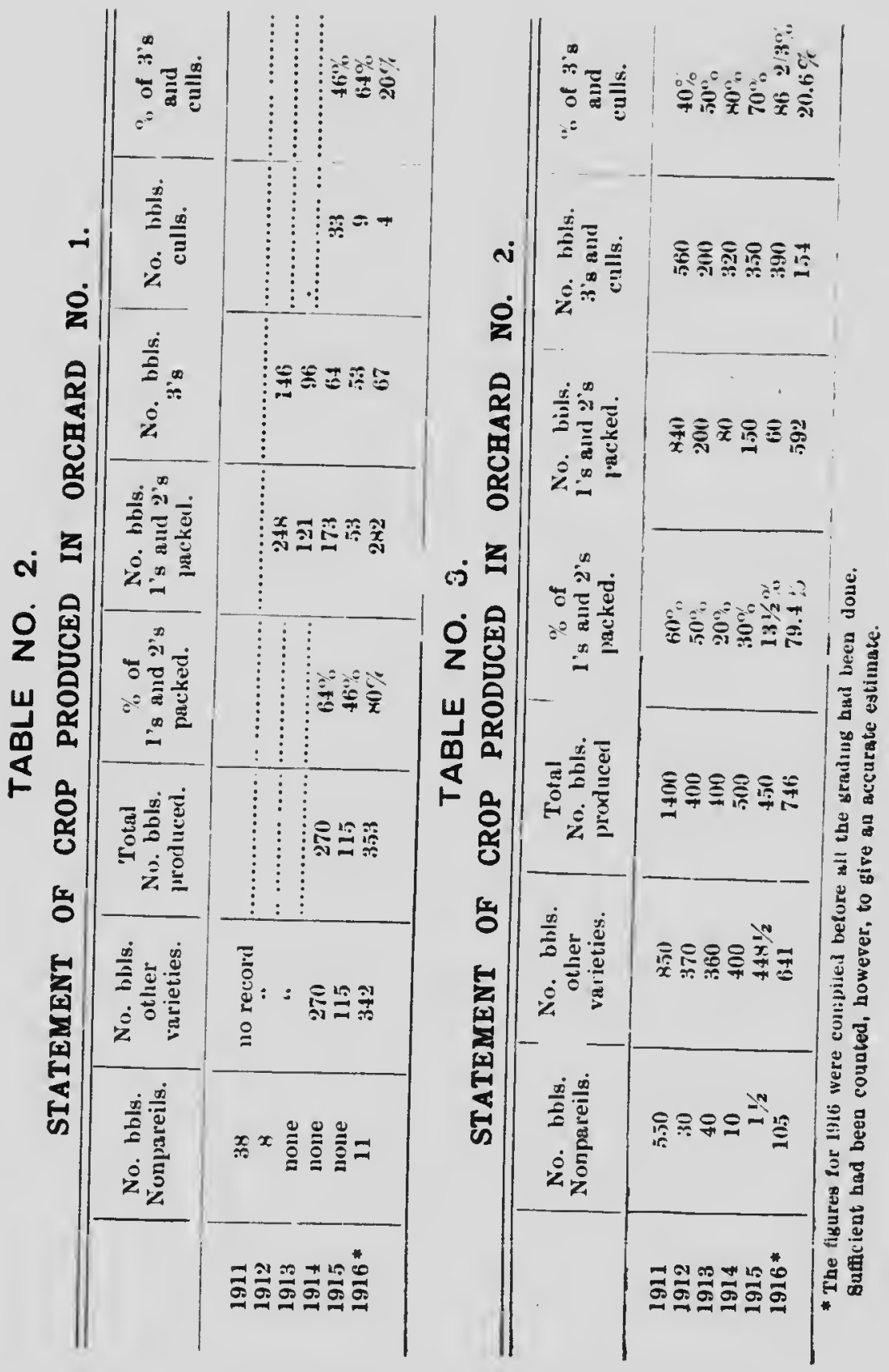




\section{Results of Spraying.}

The result of our spraying was a suecess as far as killing the inseets was eoncerned. A fiw insects naturally eseaped unharmed, as in all field experiments, but their numbers were inconsiderable, and they were unable to canse appreciable damage. The spreaders were found to increase the effectiveness of the spray, and to culable the samp amount of material to cover considerably more surface.

The pears in the sprayed orehards were earefully watehed as soon as the adults began to appear. The conclition of the pears would form a good intieation of the silecess of the work, sinee any inseets left would be certain to seek ont and puncture this frut. For the first five lays after the adults began to appear seareely a winged bug conld be fomnd in eitleer orehard, but finally they began to appear, thongh in surall numbers. It is known that the adnlts are strong fliers and that they are attracted to the frnit of pear for consilerable distances. That these bugs flew in from neighboring minprayel orehards is made evident by the fant that in oreharel No. 1, where the pear trees were seattered all through the orchard, only those on the outside suffered to any extent, those at the centre being practieally mularmed. The produetion of perfectly clean pears in infested loealities requires the virtnal exterinination of the pest, not only in the pear itself, but in all surromonding apple trees. Thongh the owner of orehard No. 22 lat not picked any marketable pears for the past three years. this year fifty-two busleels of fine smootli pears were gatherel, as well as four bushels, more or less clamaget by the loug, but practieally all saleable.

The ehief benefit to these orchards was undonbtedly done by the spray before the blossoms. A careful search was inade in both orehards, before the second spray was applied, and it was found that scarcely enougl insects had escaped after the first spray, or hatched ont afterwards, to warrant the application of a second. Nevertheless, jn order to perfect onr work, a second spray was given.

Tables number 2 and 3 , while incomplete, will give an i:lea of the crop in the orchards sprayed for the past few years, as far as records have been kept. It should again be noted that maximum results in crop production cannot be expected until the trees have had a cliance to recover from the injury they have receivel. This is true of orchard No. 1, where the 


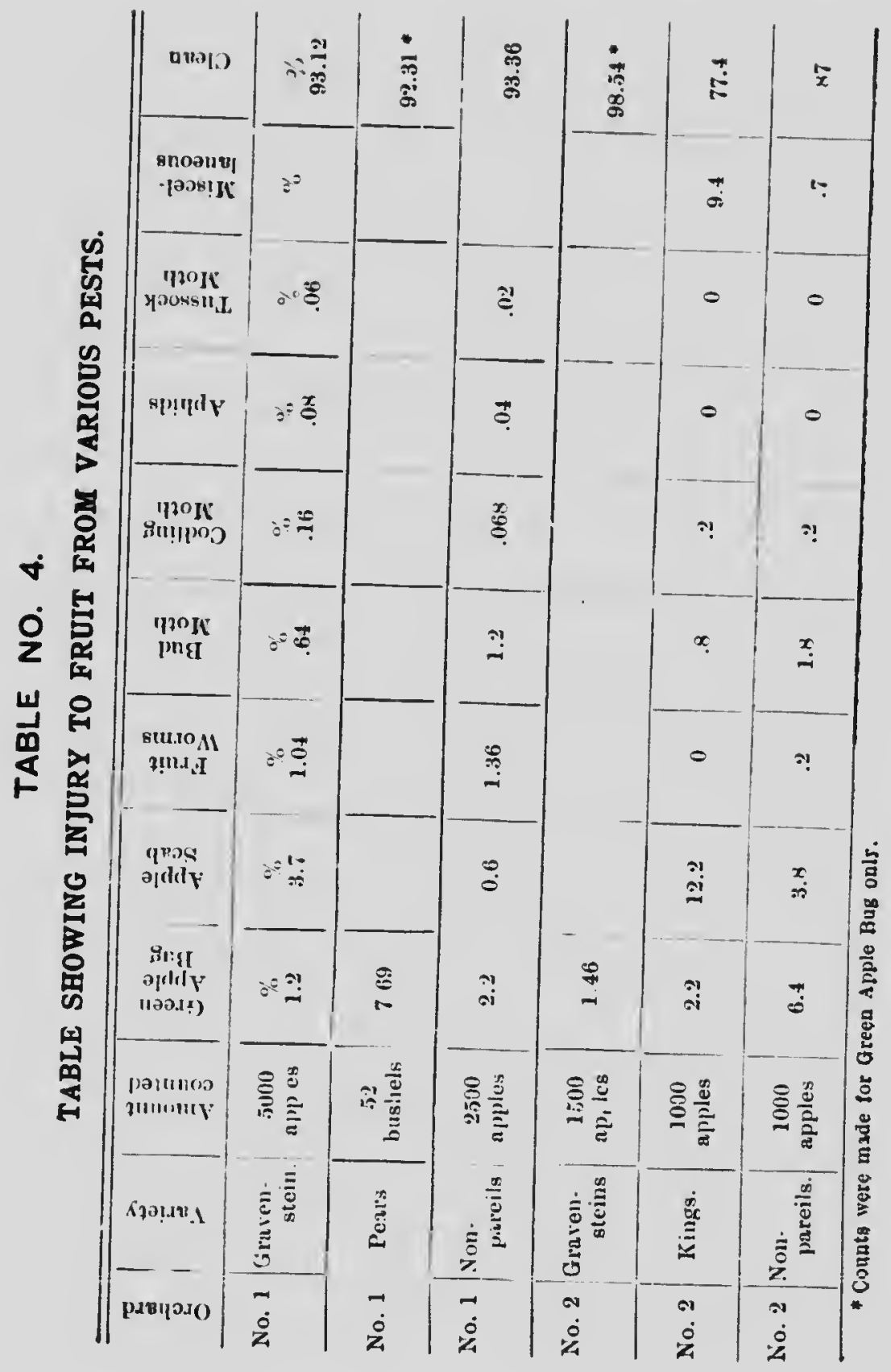


Nonpa! rils, partienlarly, wele so weakened that growth linl

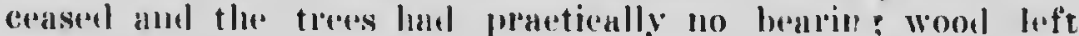

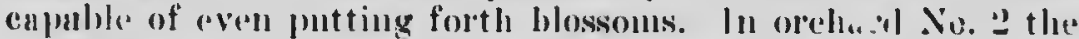
tromble was further eompliented lov a bat infestation of Finoperall ('ank:" (Nectria titissima), so thut betwern the injury dore to the bug and that dene to the distense, some of the treess were practically destroyed. All of them. lowevel, showerl rill

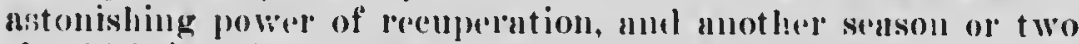
shonlal bring them bark to their former healthy conclition.

Table number 4 will be of interest us showing the varions pests that attacked the fruit, eansing a proportion to

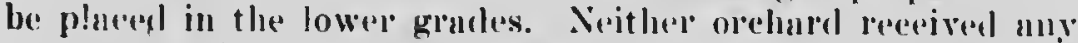

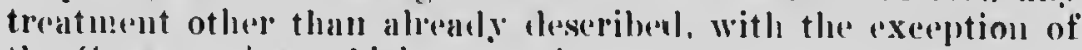
the Gruvensteins, which were given an extru spruy with line? sulplour lụ tlue owners.

\section{Misccllaneous Spraying Experiments.}

In atclition to the foregoing muin experiments, ser:e!a!

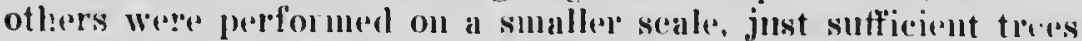
being spraperel to give ns a fuir test.

(a) Different times of spraying.-A single spray, wing nicotine sulphate in the regular strength was alplied in five distinet periodis in the terelopurent of the blossoms:

(J.) When the blosson petuls began first to show pink,

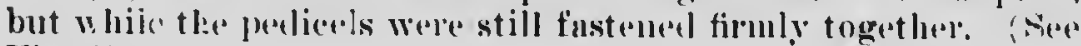
Fig. 1).

(11.) When the blosson potals were showing pinl ant

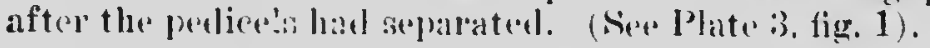

(III.) What the blossen petals had partly opened, int

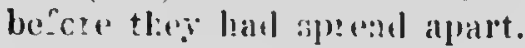

(IV.) in full b!oom, in which ease the poison wins left ol:t. so as not to injule visiting bees.

(V.) Just after the blossoms fell. (Sec Plate 3 , fig. :

(VI.) One week after the blossoms fell.

In the case of spray No. 1, it was necessary to do the most thorough work possible in oreler to seenre iesults Further-

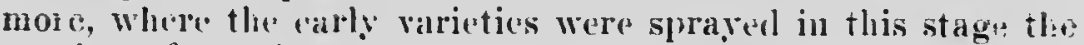
number of new in:sects that hateherl subsequent to the applica- 
tion. Were sutticient, in some cases, to mullify the results. This is, therefore, not an ielenl time to spryy, lont if gerent cure is

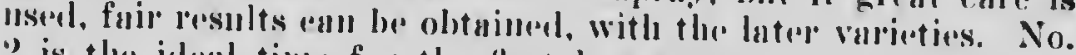
2 is the idenl time for the first bug sprey. mon ordimarily it gives a rensombly goot eonteol of the pest. "aren when no other

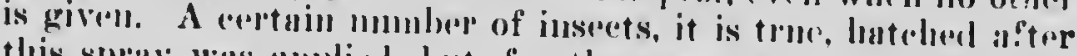
this spryg was upplient, but, for the most purt, they elicl little lamage escept where the sot of frait was light. In these mases

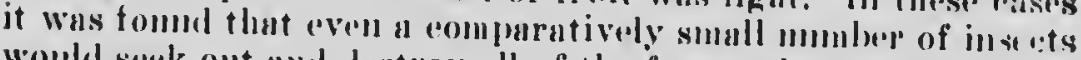

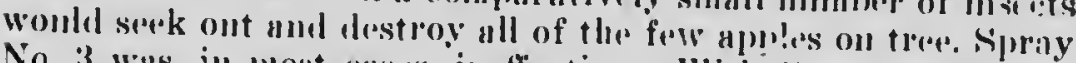

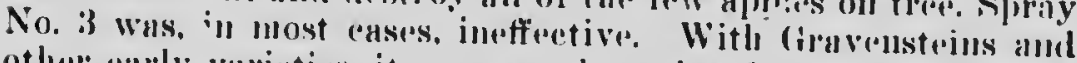

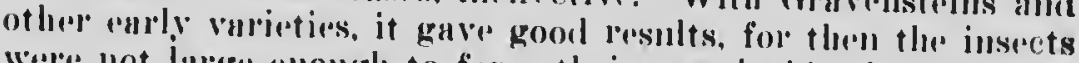

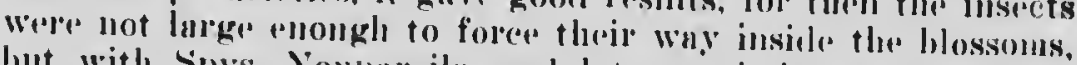
hut with Sins, Nonpareils, mul latep varietics, a proportion of the inseces were large enough to foree their way into :hes

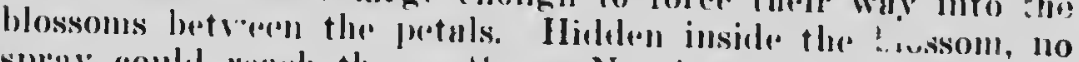

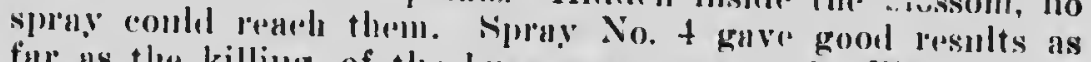
fur us the killing of the hugs was concerneel. Where very mmmeroms, howevere, they dial a considerable amomut of injury to the blossoms before it was upplieel. Spryying in full blom

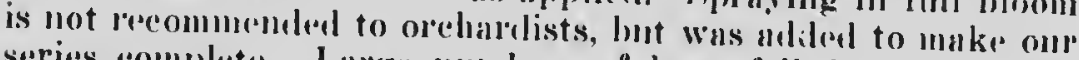
series complete. Large nmmbers of bugs feil from the trees floring this spray. As tor spray No. 5. While it was not formd impossible to destroy thre insecets nt this time, thre task was

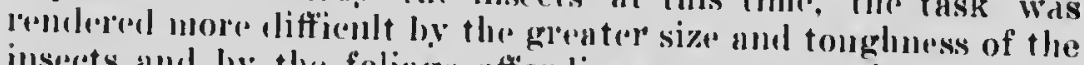
insects and ly the foliage atfording more proteretion. It was

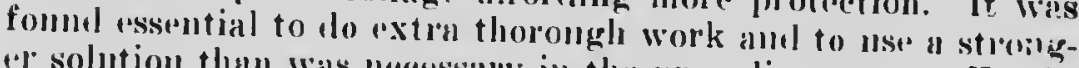
"r solution than wis necessaly in the preceding spray. Furthermore, consilerable damage had already beren done to treses where the inserets were plentiful. Sipray No. 6, and all sulse-

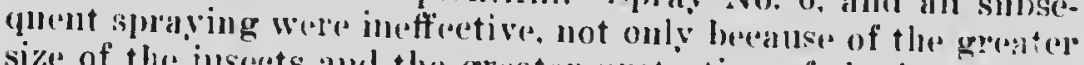
size of the insecets and the greater protection of the lan ve; but

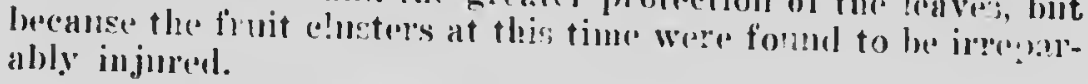

\section{tostine : \\ (b) Materials \& Nozzlos.-The follcwiln materin's were}

(1.) A combination of fish-oil soap, calbolic acil, and soluble sulphur, sold mulce the trade name of "('ylla-afis." "To a portion of this material Thomsen's " Triphunhe" an'sizate oi lead was adeled as a poison. 
(11.) A spray made from the following folmula : Soluble suiphur............ 21/2 lbs. Fish-oil sonp (soft) .......... 19 l!s. Crude earbolic neid........... 1 pt. Wuter.................. 160 gals.

To a portion of this prepuration we added tripluabie arsenate of lead as a poison.

111.) Fish-oil soup (Soft) used in strengtles varying from 1-6 to 1.10; both alone and with soluble sulplanr.

(IV.) Lumalry soap (hard) nsed us above.

(V.) Nicotine smlplante (Blacklenf 40) was used in strengths varying frou $1 / 2$ pint to 1 pint for cach 100 gals. of spray. It was used alone and in condbination witl lime sulphur, soluble sulphur and harium sulphur. To a portion of each of these combinat: ons flour paste was added as a spereader, and in the ense of the soluble sulphur combination, sonp was also trested for this purpose.

Fach siparate combination was alividel iato "2 parta and applied, one using a Friend "drive" nozkl, und tho other using a "calyx" nozzle. The results showel that the type of spray nozzle employed had a great denl to clo with the sucesss or failure of any material used. To clestroy the insect the si nust. come into contact with it and preferably strike it whin corce. It is therefore not sumprising that none of the materials used gave altogether satisfactory results witl: "calyx" noz\%le. The wicle spray thrown by these nozkles, mul the mist spruy given by others in common nse, is not alapted for alriving the liepuid in between the blossom peclieels, ewrled leaves, ete., in the same way as the strong, narrow spray throwa by the drive noz\%le. This is particularly tras in the "ffter-blossou spray, owing to the greater size and density of the folinge, but is quite noticeable in that applied iefore the blossoms. The only really satisfactory results were obtained by this type of nozzle. Fair worli may be done with the orlinary nozkles if extraordinary care is ta!en, but the greater amount of time? neessary, as well as their milonbted inferiority for this work, counts aganst the: use.

Sprays No. 1 and 2 gave good results, rven when the illsects were half grown or over. It is interesting to note that these two sp' "rvs acted as a strong repellent to biting insest.s. 


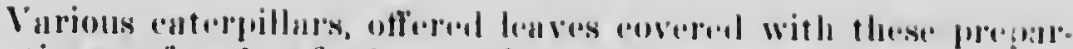

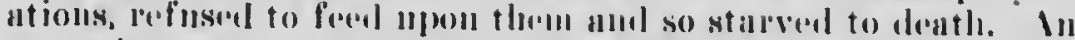

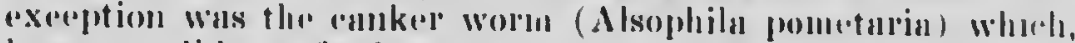

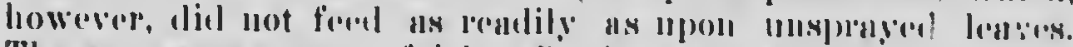

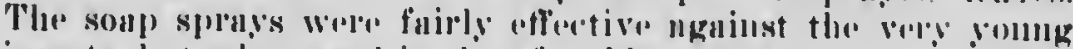

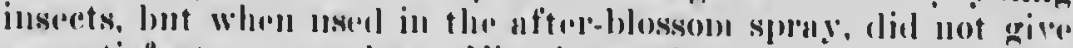

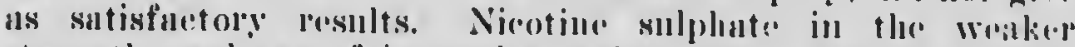

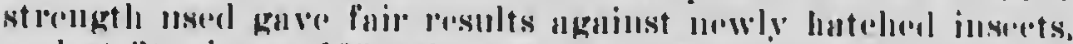
and at $: \frac{1}{4}$ pint to 100 gals. Was quite sutisfuctory for the first

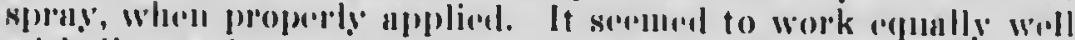

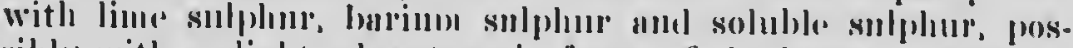

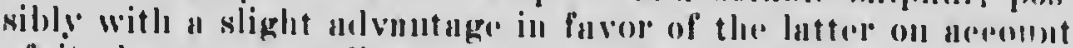

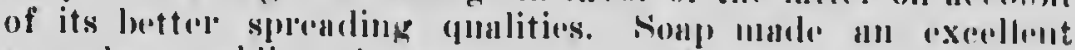

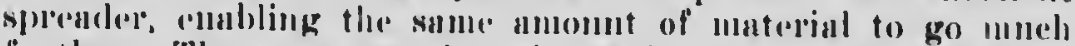

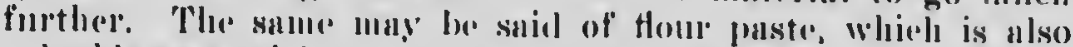

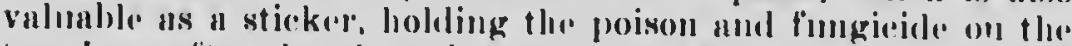

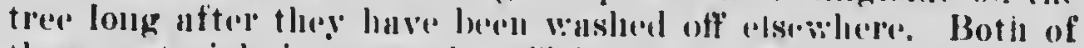

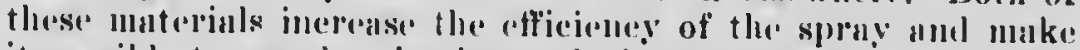

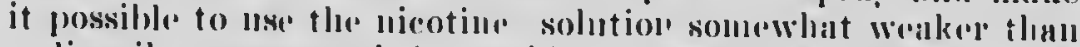

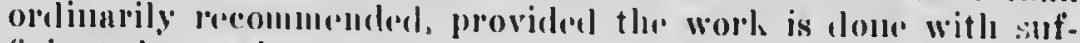
ficinut tlorongluness.

(c) Use of Different Fressure- - l'ressuly's of from 100 to

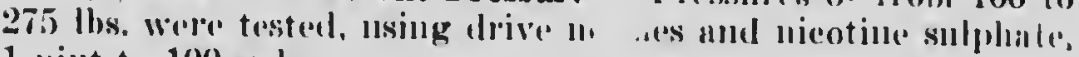
1 piut to 100 gals.

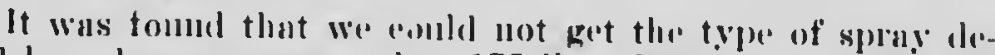

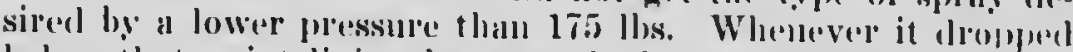

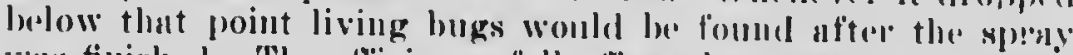

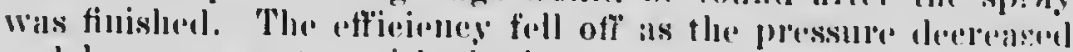

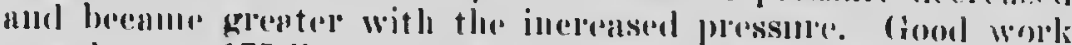

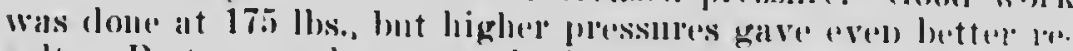

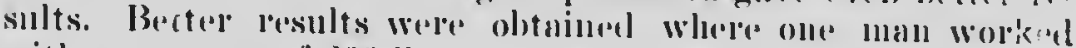

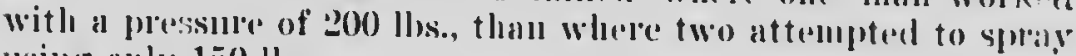
using only $150 \mathrm{llss}$.

(1) Spraying Without Banding.-Blocks of trees wele

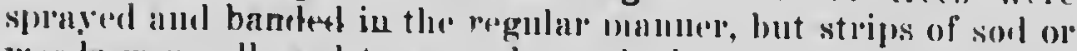
werels were allowel to glow beneath the trees. In sllell rases injury was alone by the atlults which cance to maturity on threse plants, wherevele the pest was minnerons. Peals sutfopol especially from theil wook. This was done in a locavily infested oreliart. When tested witl a light or moderate infestaibul, and also in a small orelard where the spray could be applienl at just the correct perion, the benefit frou banding was formel to be inconsiclerable. 


\section{CONCLUSIONS FROM CONTROL EXPERIMENTS.}

\section{Material to Use.}

'Tlu. most sutisfurtory mutreial to nse is niontine sulphoto

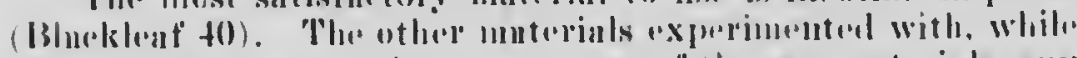

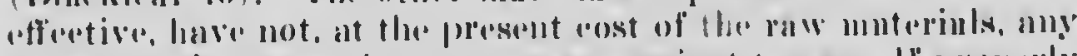

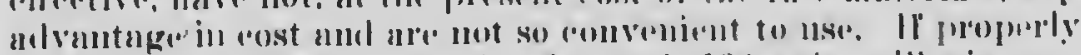

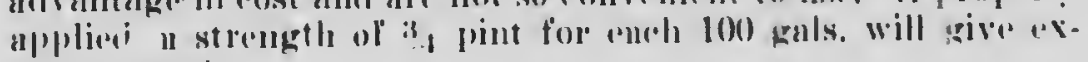
whllent results.

\section{When to 8pray.}

'The ioleal tims for the appliention of the first spray' is when the blossoms are showing pink, preferably aftere the

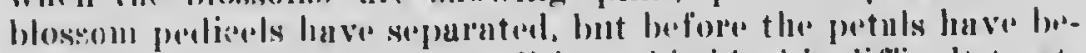

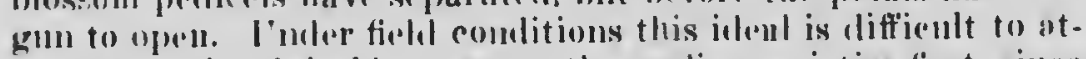

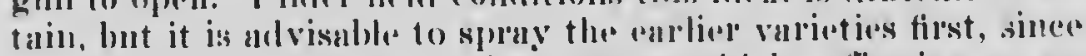
an ippliention male at a time thet wonlal be coffective on :m

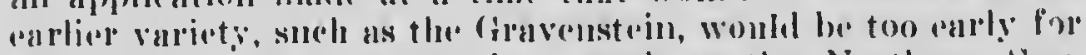
goosl results on a late viuriety, sureh us the Northern sipy.

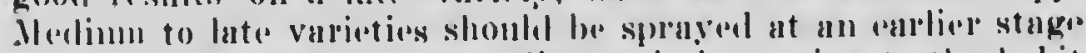
of their blossoms than the rallior variotios, owing to the lenbit of the inseret of alloring the blossoms nul eoncealing itself

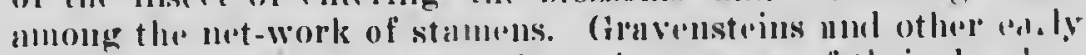

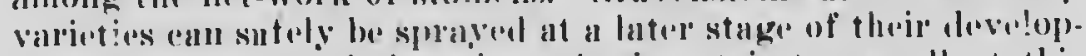
ment than late variatics. sinee the insect is too small at this time to anable it to foree its way insille the blossoms. When, howevere, the blossoms of the hite valuedies hegin to spledal npalt. prepalentory to opening, some of the insects ure larger

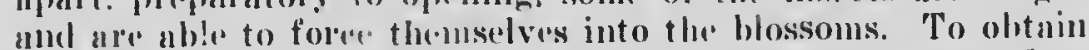

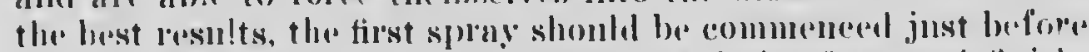
tho blossoms open, taking the "arliel varieties first, and tinishing np on tho late ones. This sprus, if timed properly, and lone with sufficiont care, will give plactieally a commereial control of the pest. Mnch hetter work enu be ilone and a werk"le sohition nserl at this time thun hiter, when greater protece tion will be atforeled by the larger lenves.

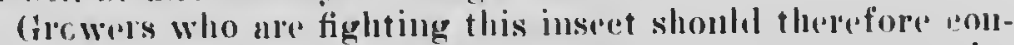
centrate on this spray, nud spale no "ffort to destroy every in-

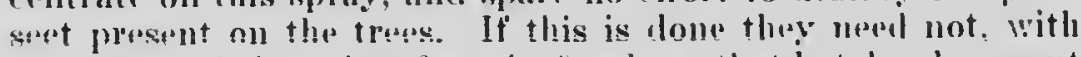
an ordinary infestation, feyr the few bugs that hateh subsequent to this spryving. Those who have only a very light infestation of the bug should not fail to give their trees the benefit of the 


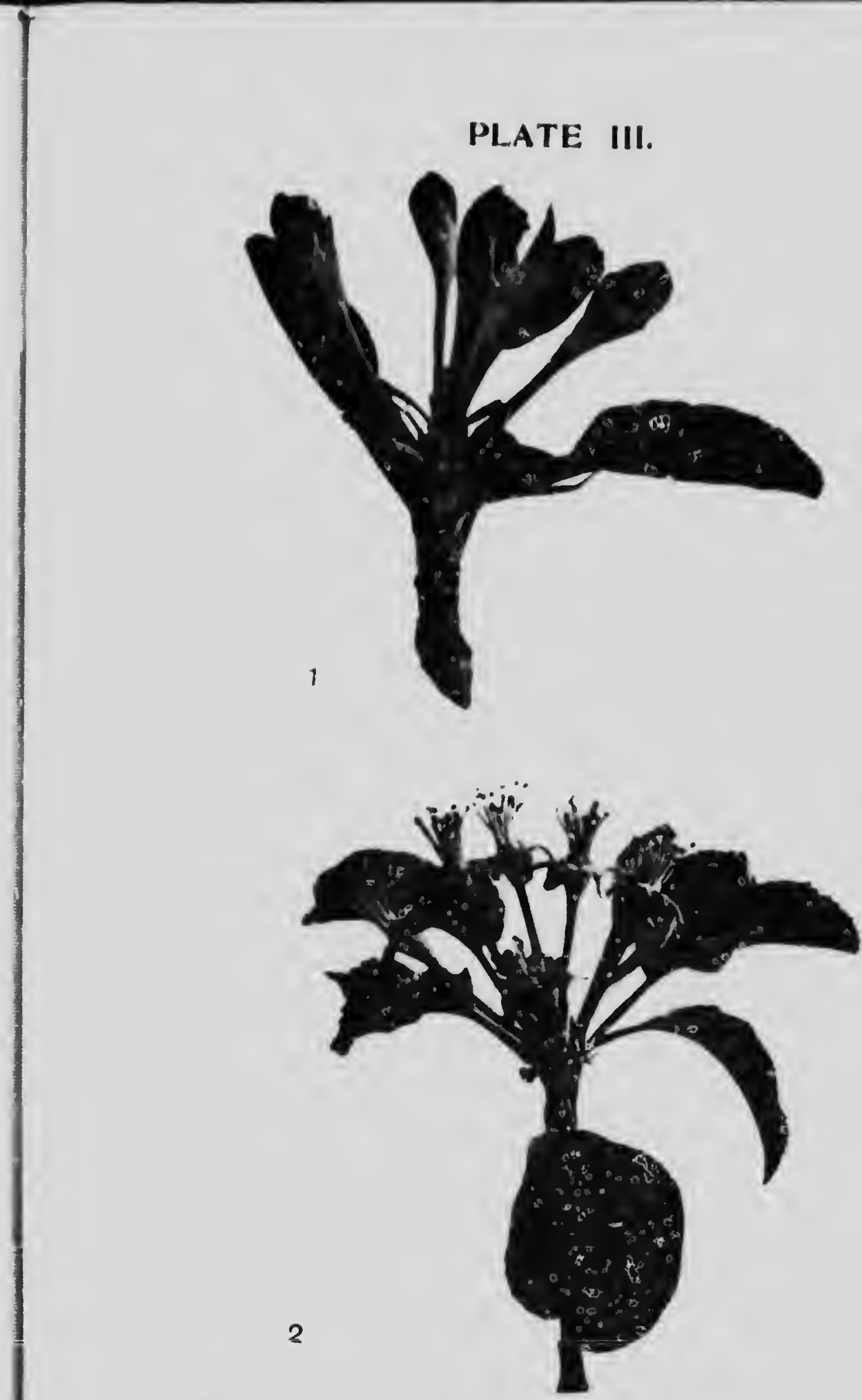

Fig 1.-Condition of Gravenstein blossoms when first spray should be applied. (Original.)

Fig 2.-Condition of blossoms at time of sccond spray. (Original.) 
spray before the blossoms. If applied in such a way as to destroy the grean applo bug, aphicls and other sueking insects will a!so be controlled, thongh this is not the ideal time to spray for these pests. This is also the most important timo to spray for the apple roab (Venturia pomi), ancl a thorough ilrenching of the trees with fungicicle at this time will be very henceficial in the eontrol of this elisease.

In ouler to catch those insects that lave hatehed cluring the blossoming periol it is necessary to apply another spray after the blossoms fall. The foliage being much ilenser at this time the task is naturally morı clifficult, but witl care cxcel'ent results can be accomplished. Whero very severe infestations exist it will usually be aflvisable to apply this spray.

Though spraying in full bloom is not recommencled, it is of interest to note that the pest was effectively controlled. Trees sprayed in bloom require no further treatment for the bug, which, however, if numerous, may accomplish consicierabie hat m lefore this time.

\section{HCw to Spray.}

The control of the green apple bug is ehiefly a mechanieal prob!em, as las been previously intimated, and more clepends upon the manner in which the spray is applien than upon any otler factor. All parts of the tree inust be reached and avery insect covered with the liquill. For this purpose a strong, 'larrow driving spray is essential, best obtained in our experiments by the use of a "Arive" nozzle ancl a pressure of 17:5 lbs. ancl upwarts.

(ontrol cannot be securecl by spraving at the tree as is eommonly done, or by going all around the outside and leaving the centre mintonchel. Fvery limb anl twig must bo followed up and down and sprayed from 'very angle, from below as well as from above. The nozzle slouli be theust into the centre of the toce, and particular care shoulal be taken to Irench all palta. The tops should be given special attenti ell, as the bugs are just as numerous liere as anywhere on the tree. Thorougluness is the great secret of success in the control of this insect, ordinary spraying being of 110 avail, and it must always be bemembered that the aim is to spray the insect, not the trees.

Some orchardists spray the entime orchard withont ever 
examining the trees to note the effect of their work. It thesefore frequently happens that muel valuable time and materi:il is consumed before it is cliseovered that the whole has been wasted. It is very important to cxamine a tree here and there at intervals thronghont the work, making certain that the spray is laving the lesirel effect. If living bugs are still found on the sprayed trees, this inclicates that still more careful work must be lone. By following this lule the fruit grow' will be savel much elisappointment ancl loss.

\section{Amount of Material to Use.}

The anomt of material to nse naturally depends npon the size amel thickness of the tree. Futhermore it is well to rem(')ulber that good spraying does not consist in merely pouring out a certain mmber of gallons mpon a tree. It is possible to use as much as 30 gallons on a moderate sized tree without it heing effectively sprayeel as far as the bing is concerned, wheroas five gallons, properly applied, might have aceomplislicel the work. Effective spraying consists in getting the ligniel on the bugs anel getting it there witls foree if possible.

At the same time, it may be useful to have a general iolea of the correct amount of material to use. In our orelarel No.

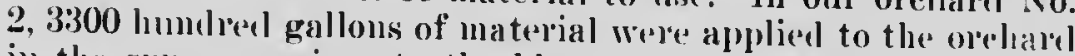
in the spray previons to the blossoms, or 12 gallons of liquid

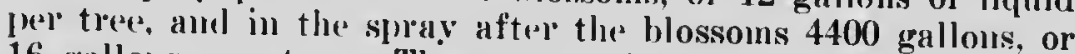
16 gallons pere tree. These trees, it slonld be remembered, were in a sixty rear olel oreharel and were consilerably larrere than the arelinge in size.

\section{Importance of Pruning and Thinning.}

Whatever views may he helel as to the value of proming amel thiming form a loorticultural stamelpoint, there is no loubt that it is essential to the suecessful control of this pest. T'roes that ale too thick to be readily aceessible to the spray, or that "ll' too high for all parts to be l'eached, eamnot be suceessfilly treated, ancl moreover, mnch material is wasted. No one shonld attempt to treat an outbreak of this pest in his olelialel withont having first atteneleel to this inporant matter.

\section{Necessity of Banding Trees.}

The only practieal way to prevent those bugs which late fallen to the gromul from returning to the trees, is by the lise 
of tanglefoot bames. ('ould the spraving of the trees be followel by the harrow or cultivator, this might do equally well, int a secomel team is rancely avalable for this purpose. A wiele loeavy banl is not neecssary, since these insects do not bricke it after the manner of canker worms. In fact, only a sliall proportion "ver stick to the bamel at all, which is only applied for the purpose of kerping them from climbing the trees. The spot which is to be banded should be first serapeal with a blunt instrument. and a thin narrow banel of the tanglefoot applied with a palclle. ln very light infestation bancing might be safely omittel, but in the experiments comblneterl in bally infesterl orcharels, it was fouml to be essential.

\section{Necessity of Clean Cultivation.}

Nymphs dropping from the tree have bern shown to be able to subsist on various plants and if preventerl from aseanding the trees, they will lemain fereling on snch plants netil after tiney have reacheel the alult stage, when they will immeliatel! seck the trees amel continue to feexl for some time 11 onn the fruit. As has previonsly beren pointerl ont, consielerable clamage is clone to penes by the alult insects. While they are not so destruetive to the apples in this stage, they deposit the "gge for next year and it is therefore most important that as maly as possible of the insects be alestrovel before they leach matiurity. Since the achult stage is not reached by all inscets nutil about the emel of the first werk in .Jnly, it is essential that sufficient coltivation to kerey) the werels in check is given the oreharel mutil this time is passed. This lecommentation leefers fanticularly to bally infesterl oreharrls.

\section{The Use of Spreaders.}

The material can be mate to go finther and male more effective by the use of spreaters. Flour paste is an excollent spreater ant also causes the material to adhere firmly to the leaves, thus affording longer protection against fungi and biting insects. This material is prepared in a similar mamme to that nsed for wall-paper. In making the paste a pomme of thour is nseal for each gallon of water, the thom being first tholon: ly seremeal so as to break mp all lumps. It is them make into a thin batter with coll water, ancl stirred into the required amonnt of vigorously boiling water. It should then be removed fom the stove anil stirred mit a paste is formed. The fore- 
going metlood will nsmally give sufficient cooking to maks a good paste, but it may be left on the stove a little longere if necessaly, and stipred to prevent it from burning to the hot tom. Insufficient cooking gives an ineffective paste, while over'ooking eanses it to become hard and sticky, so that it will - t mix with the water ane. .nses the nozzles to clog. The te should be added to the mixtmre through a sieve and ily 1. es should not be forced through by hand, but by the ies: of water. Fron 3 to 4 gallons to each 100 gallons of si,ray shon!d be inserl.

Soap has also been used as a spreader and is exeellent four this purpose. It shonlel not, however, be nsed in combination with lime sulphur or with arsenate of lead or arsenate' of lime, but with soluble sulphur it can be used with perfect siffets. A combination of solnble sulphur and nicotine with a soft fisl-ail soap added at ihe rate of 2 qts. of soap to each 100 gals.. Was used with excellent results.

\section{Burning From Heavy Spraying.}

It was fonnd that lime snlphor was liable to injure folinge when used in the large quantities necessary ir spraying for the hing. Since, owing to the lacl of time, it is out of the cluestion to make separate applieations, we experimented with the lime sulphmr in redheed strengths. It was fonnd that by using commereial lime sulphor testing $33^{\circ}$ Banme in the strength of from 1-50 to 1-70, the danger from burning was greatly riduced. It will naturally be asked whether these strengtlus are sufficient to control apple seal, since this discase is onte of the main considerations in orehard spraying. We were somewhat surprised to find that trees sprayed with solntions as weak as 1-70 remained comparatively elean and free from seal. In fact they were in a much better conclition than trees that had received only moderate sprinying with strong solntions. No effort was made to deternine the minimm strength to be employed for apple seal, since this was not the object of the investigation, int this season mnch weaker strengths than originally nsid were satisfactory. wherever the work was done in this thorongh mamner. Whether we wonld have obtained the same satisfactory results against the seab under conditions more fav. orable for the development of the fungis, still remains to be seem. It may be neeessary to sncrifice something in the way of seab control in order to destroy the bug, except in small orehards where separate applications can be made. 
Where nicotine sulphate was employed in combination with soluble sulphur, no poison being included, injury to the foliage did not result. The fish-oil carbolic mixture, used in combination with soluble sulphur, and "triplunbic" arsenate of lead, caused considerable burning, but little injury resulted where the arsenate of lead was omitted. No burning was caused by the Cylla-afis when used without an arsenical poison.

\section{Cost of Ireatment.}

The cost of spraying will vary with the size of trees and the number of sprayings found necessary. The cost of nicotine sulphate (Blackleaf 40 ) at $\$ 10.75$ per $10 \mathrm{lb}$. tin, for one spray in Orchard No. 2, amounted to $\$ 50.55$, or approximately $19 \mathrm{cts}$. per tree. To this inust be added $31 / 2$ ets. for the cost of tanglefoot for each tree. Thus the cost of material alone, to obtinil a cominercial control of the green apple bug, anounted to $211 / 2$ ets. per tree. For two sprayings of Orchard No. 1, the cost was slightly uncler 33 ets. per tree.

In considering these figures it must be remembered that we harl to deal with unusually severe infostations ancl cxceptionally large trees, and that, as we now know, we can safoly weaken the strength of our mixture, particularly in the first spray, provided we do sufficiently careful work. Hat we reluced the strength of the material in our first spray to $3 / 4$ of a pint for each 100 gals., the cost in No. 2 oreluarl, where the trees were largest, would have been reduced to $171 / 2 \mathrm{e}$. per tree In none of our work was any attempt made to save material, all our efforts being concentrated on the destruction of as many bugs as possible. Even with this, many may be inclined to aṣk if the cost is not excessive, in proportion to the end gain.arl. Those who have spent large sums on their orchards for years past, in cultivation, fertilizing, underclraining, otc., only to sere the crop fall off' every year until it is finally greatly redued, if not entirely alestroyed, will not be likely to lesitate regareling this expenditure. The great difficulty lies in the fact that the absolute necessity for work of extreme thoroughness is seldom realizel when the first attempt to control the pest is made. The result is that, not only the erop, but also the money spent in attempting to produce it, is lost. Where. however. the precautions outlined in this bulletin are faitlufully followerl the cost is inconsiderable when compared with the benefit to be gaimed. Many growers have now to weide whether they will have the best of their land encumbered with an umprofitalle 
orehard, or whether they will expend the time and money necessary to eradieate the pest.

\section{General Considerations.}

It will be seen from the foregoing diseussion that the control of the green apple bug is no ordinary task. The time consumed in spraying for this pest is ennsiderably greater than when it is only neeessary to do ordinary work. It is therefore doubly important that the spray pump and engine should be in good order and that the facilities for filling, ete., are such that no time is lost. Many preeious loours are wasted for the want of a little attention to the maehine, before the spraying season eommenees. When the sueeess or failure of a eertain spray depends upon getting it on at a eertain eritieal period no preeaution slould be negleeted to prevent umneessary delays. Some orehardists ean fill their tank and mix their material in as sloort a period as ten minutes, while others require as long as forty-five minutes to an hour in doing the same work. Others have gone to the expense of purehasing a power outtit, but in plaee of a regulation tank make use of one or two $40 \mathrm{~g}$. I. barrels. This meeessitates the same amount of work for every 40 gallons that it should take for four or five times the amount. Sueh delays as this make all the differenee between profit and loss in spraying the oreharl. With proper faeilities and the use of drive nozzles, a good outfit should put out at least 1,000 or 1,200 gals of spray per day, but this will not allow much margin for tinkering with the outfit.

\section{Causes of Failure.}

Numbers of growers have attemptel to control this pest without results eommensurate with their expencliture and experience has shown that the negleet of some very slight preeaution is often responsible for such failures. Some have failed to band the trees, others have not kept lown the weeds, and these have had their efforts defeated by the inseets whieh made their way baek to the trees again. II any have not done the work with that thoroughness that is an essential to sueess. It is hard to make the average sprayer realize the amount of eare neessary in order to lave the liquidl reaeh every insect. Others, who did the work as well and thoroughly as was possible under the eireumstanees, failed beeause they did not secure the right type of spray. These minst remember hereafter that with ordinary mist nozzles and low pressures it is next to impossible to control the bug. 
The statement has frequently been male that the coarse speray thow by nozzles of the drive type is productive of wasterl material. This trpe of spray, however, makes it possible to place the splny just where it is required and, if skillfull: hamblet, should not result in undue waste' of material. In foreing the liquid into all parts of the tree the outer leaves will naturally sheel some of the material, which drops to the gl'omm. This must simply be regartled us inevitable, for the man who is afrail of "Wasting spryy" is responsible for most of the failures to control the bug. That an adequate anount of unterial, properly appliet, in conjunetion with eareful pruning, enltivation and banding, will control the pest, has besn definitely provent, both by oun own experinents and by the experiener of several practical fruit growers.

\section{ACKNOWLEDGEMENTS.}

The author desires to extend his most hearty thanks to :11 those who have assisted him in any way throngliout the eonrse of this investigation. Messrs. H. G. P'yyne and W. E. Whiteheatl hare helped! in the study of the life history of the insect. Mr. L. G. Sammers is responsible for the colored plate and for general laboratory assistance. Mr. C. B. Goolerhan assisted in the experimental work on varions oecasions, ant most of the photographic work has been performed by him. The sureerss of the spraying and other field experinnents is largely alue to the allnest, prinstaking efforts of Messrs. J. I'. Spittall ancl (: F. I'. Whitman, who earliet on this part of the work. 


\section{BIBLIOGRAPHY.}

Owing to the fact that the Green $\Lambda_{p}$ le Bug has only reecently heen deseribed, and is apparently confined to this part of North America, very little has been published regarding it. Owing to its vely elose relationship to the false tarnished plant bug (Lugus eommunis Kuight), and the similarity of their work, references to this insect are likewise incheled.

1. 1 K46 Lintnc:, J. A.-Rept. Inj. Ins., N. Y. 3:110. 1885.

Describes injuries to pcars wilich are attributed to I. pratensis, which are coubtless the work of communis.

2. 1891 Lintner, J. A.-Rept. Inj. Ius., N. Y. 7:348, 1890.

Describes work of Coicophora sp. to pears, stating in a foot-llote that part of the injury was subsequentiy found to be in part the work of L. invitus Say. (?) No doubt the culprit in this case was also communis.

3. 1893 Lintncr, J. A.-Rept. Inj. Ins., N. Y. : 288.1891.

Note on clamage cone to pears by $L$. invitus Say, whicn is which he widespread, but not serious. Describes work locelity, attributed to L. pratensis on pears in another locality, which reads ilke a lescription of what we now rccognize as the injury of $L$. conmunis.

41893 Riley, C. V.-Insect Life. 5:18

Note on injury due to Lygus sp. at South I3yron, N. Y.

5. 19M0 Lowc, V. H.-Injury to peaches by the Tarnished Piant Bug, N. Y. Agr. Expt. Stat. Bai. 180:135.

Records injury to pcaches which he attributes to Lygus pratensis, which might possibiy have been mistaken ior

6. 1901 Howard, Dr. L. O.-U. S. Dept. Agr. Ent. Bul. U. S. 30:93. A note recording attack of Lygus invitus on pedclics the insect sucking the juice from the young fruits, causing them to shrivei. This is said to be the first record of injury donc by the insect. with which the author is acquainted.

7. 1895 Siingerland, M. V.-Cornell Exp. Sta. Bul. 93:221.

Notc on injuly to pears characterized by "hard, knouty kernels, which are so often accompanied by irregular piant bugs (L or cracks." This injury was attributed to piant bugs (L. communis?) or the pium curculio. 
8. 1010 Parrot, P. J.-Rept. o: inj. Ins. West N. Y. Hort. Soc. Proc. 55:114-119. Figs.

During 1909 It was cilscovere that gnarly pcars, the fruit being situnte! and Irregular in shape and more or less markod with hard, corky spots, wins causcd by L. Invitus Say. In one orchard $75 \%$ of the fruit was damaged, 50' being renicred ueciess. The insect referred to is ('ommunis.

9. 1913 Parrot, P. J. \& Hoicklss, H. E-The False Tarnlshed Plant Bug as a Pear Pest, N. Y. Agr. Exp. Sta. Bul. 368. (Piates 8; Figs., 7 ).

This is a 20-page bul!ci'n contnining a brlef account of the history, injurtes, habits, bio!ogy and methods of control of Lygits ccimminis, wh:ch ls referred to as Lygus lnvitus Sny. A cescript!on of the c. zrent stages is glven and the name. "False Tarnished Plant Bug", is proposed as a popular nanic for the insect.

10. 1915 Brittain. W. H.-Rept. Prov. Ent. Rept. Sec'y. Agr. 1914. A brief note regarding discovery of damage done by the Green App!c Bug to pears and apples throughout the Annapolis Valley, N. S.

11. 191; Kulght. H. H.-Observatien on the Oviposition of certain Capslus. Jr. Ee, Ent. Vol. 8, No. 2. : 296-297.

Desrribe: the cictalls of oviposltion of a female Lygus invitus on a pear twh. The insect here referred to is $L$. communis and not the Invitus of Say.

12. 191. Brittain, W. H.-Tle Green Apple I3ug. Proc. Ent. Soc. N. S. 1915. No. $1 . \quad$ : 43-47.

A stmmarized account of ob crvations mace regarding the inscet during the year 1915.

13. 191 Britta!n, W. H.-46th Ann. Rept. Ont. Ent. Soc. 1915. (3 Plistes).

More extcned acecent of the studie: mate regarding this insest curing the seasen of 1915.

14. 1916 Kinight, H. H.-Lygus cemmun:s n. sp. ('su. Ent. VoI. Nil111.. No. 10 : $346-84$ \&.

Orig:nal cescription of the species.

15. 1811, Knight, H. H.-Lygus cc nman's var. novascotlenis $n$. var. ('an. Ent. Vol. XlVIJI., No. $10 . \quad$ : 349.

Original escription of the variety. 

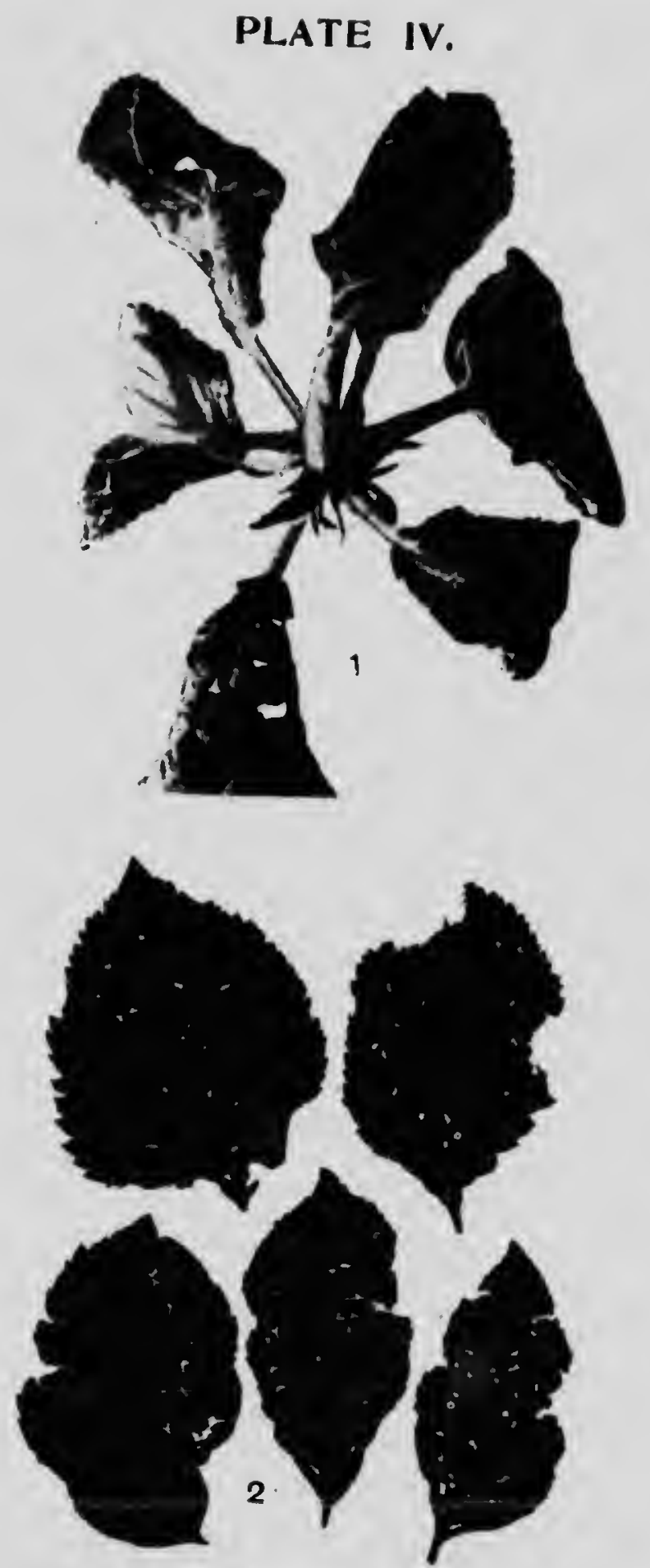

Fig. 1.-Injury to tender leakn.. Jriginai.)

Fig. 2. - Mature leaves as seen when held to the light, showing effect of former injury by the bug. (Original.) 

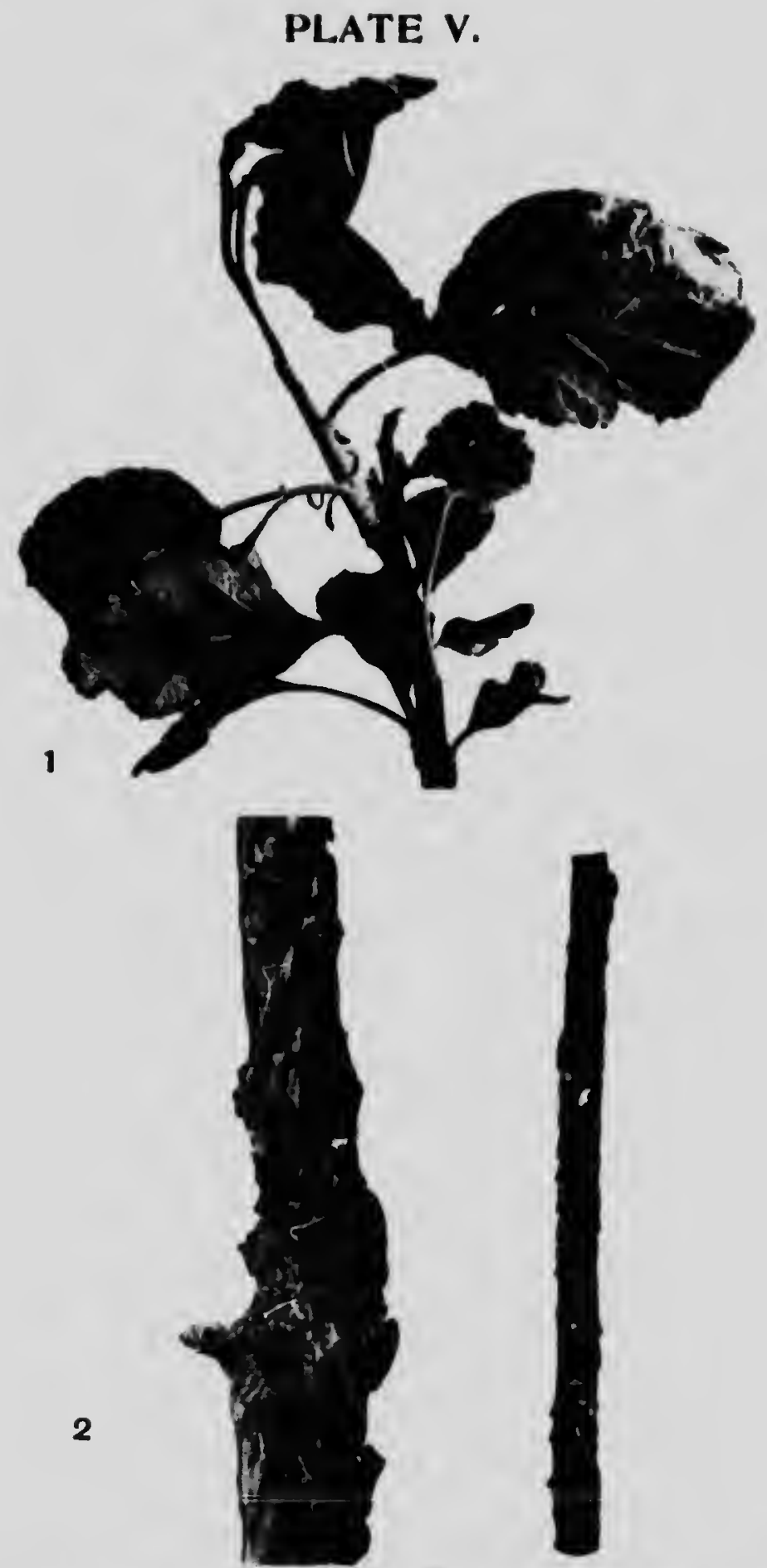

Fig. 1.-New growth injuriously afrected by nymphs of the Green Apple Bug. (Original.)

Fig. 2. Appie twige showing effect of former punctures. (Original.) 

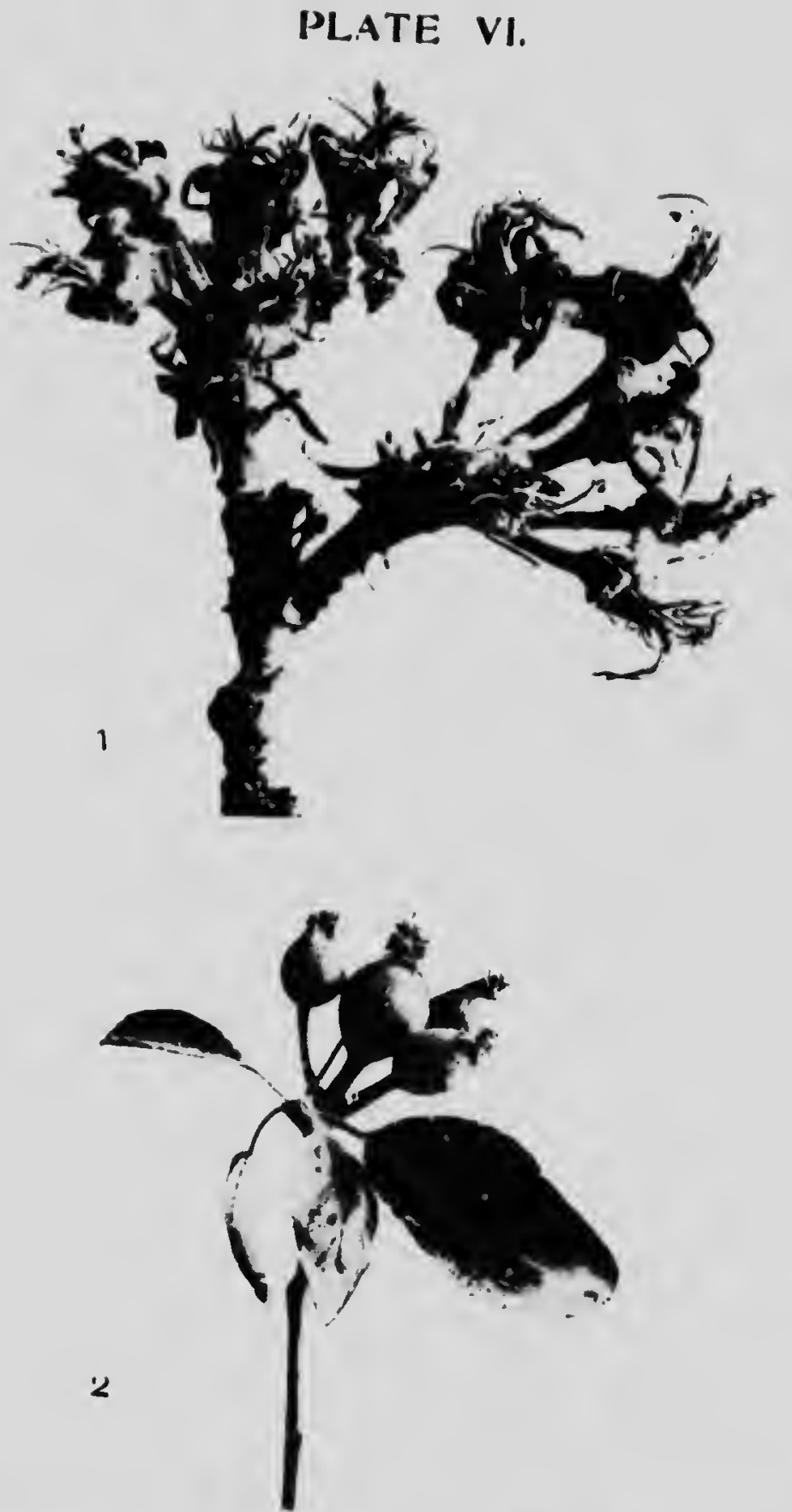

Fig. 1.-Blossoms destroyed by punctures of the bug. Photo taken two weeks after normal falling of the blossom petals. (Original.)

Flg. 2.-Uninjured fru.t spur at the same perlod. (Origlnal.) 


\section{PLATE. VII.}
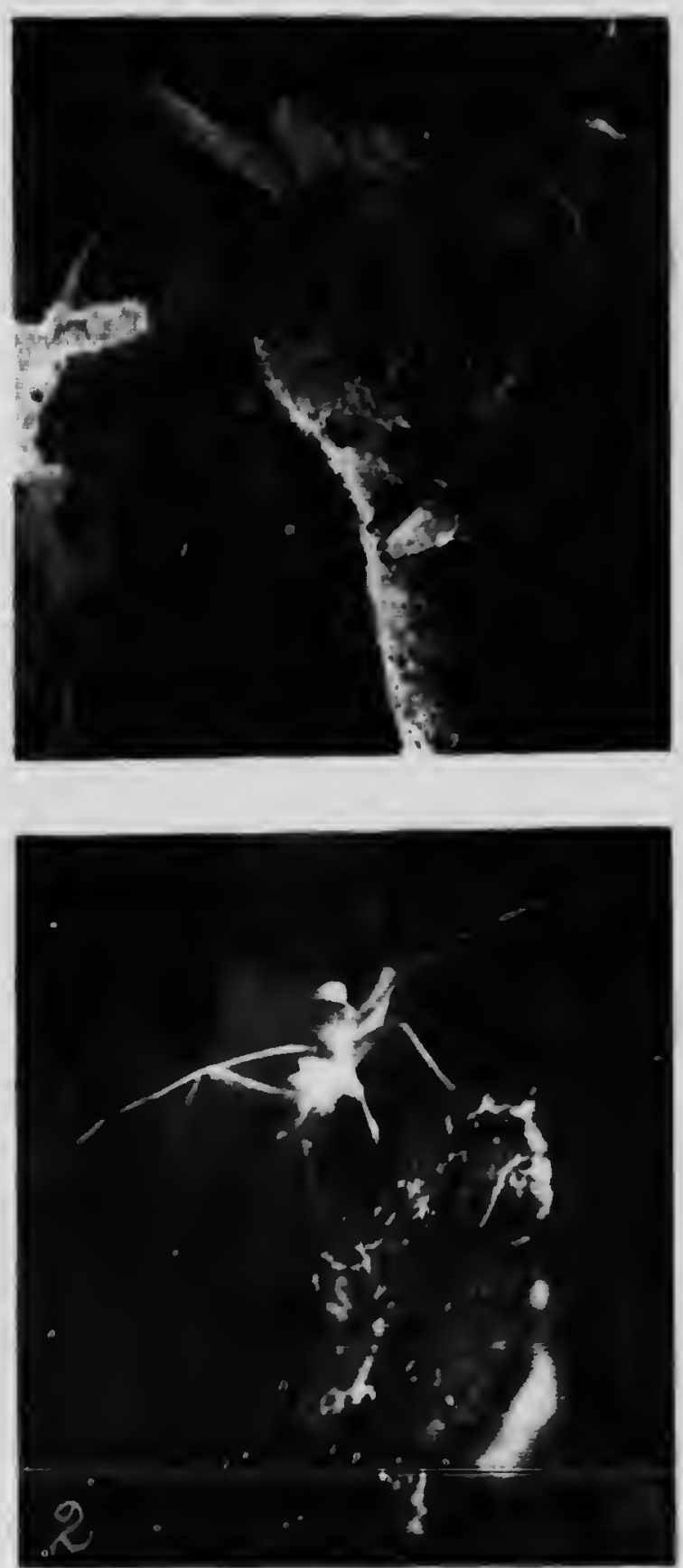

Fig. 1.-Fifth stage rymph feeding on young apple. (Original.) Fig 2. -The same seen from the front. (Orlginal.) 


\section{PLATE VIII.}
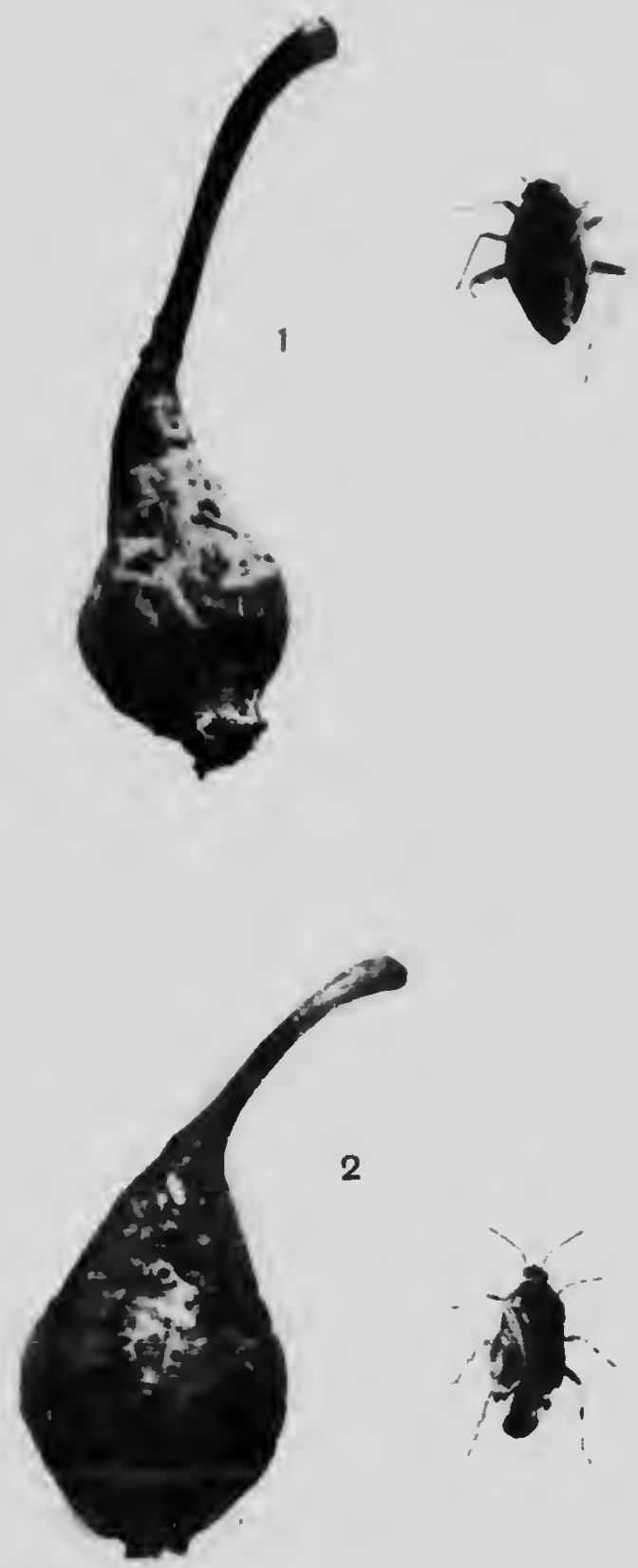

Fig. 1.-Fifth stage nymph and young pear injured by same. (Origina',

Fig. 2.-Aduit bug and pear damaged by its punctures. (Original.; 

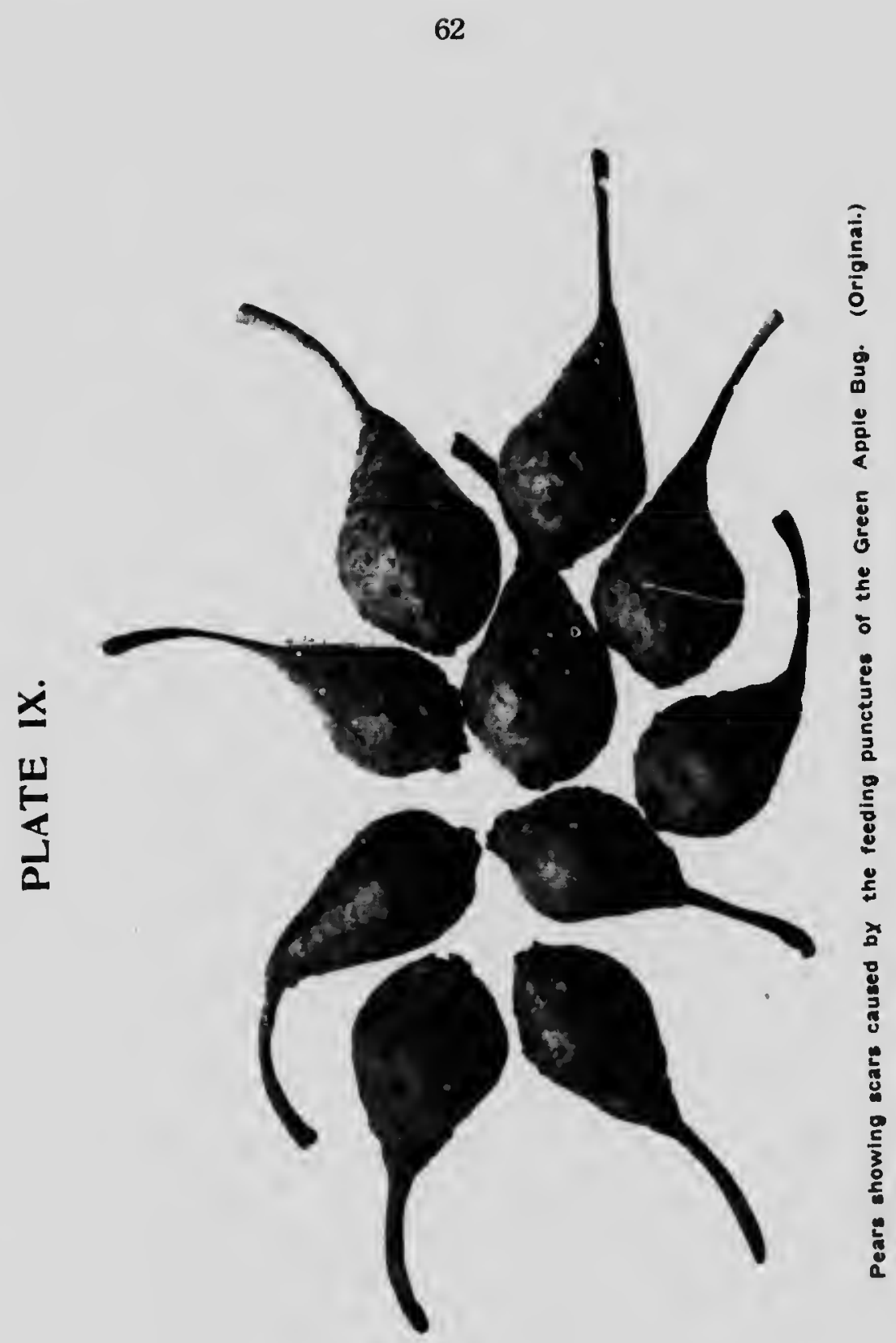
PLATE $X$.

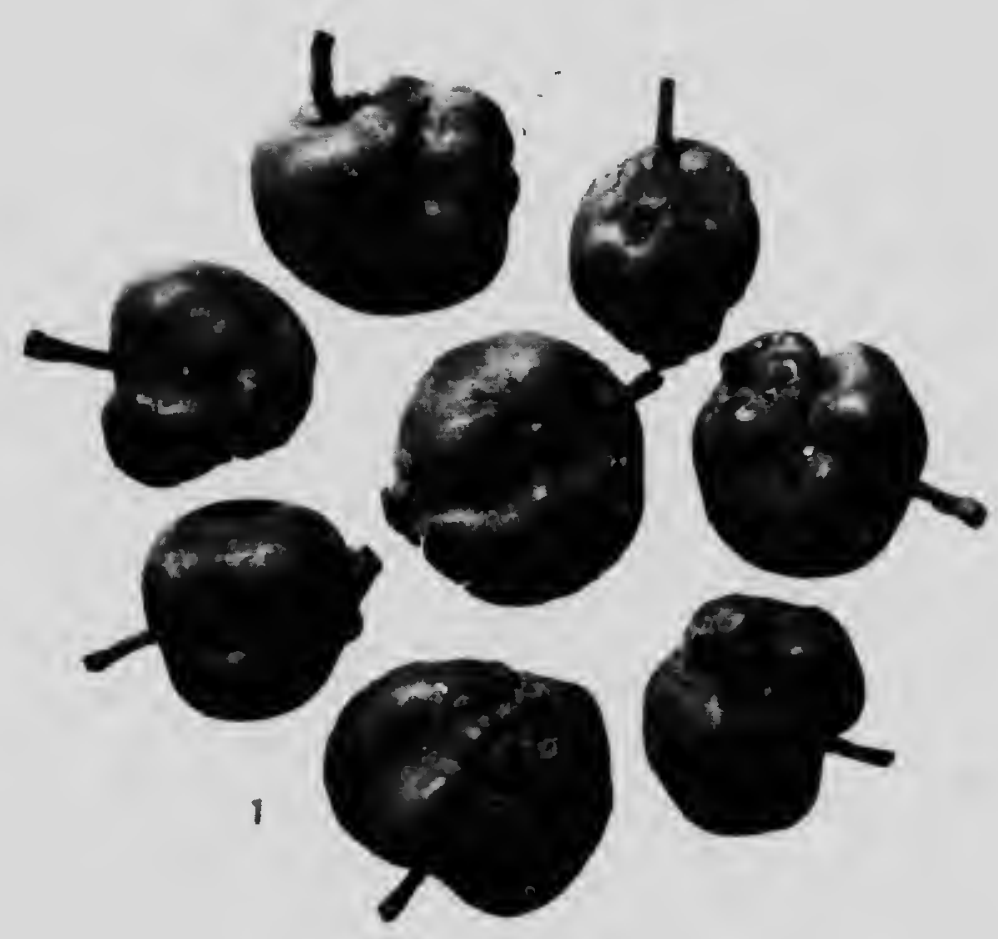

2

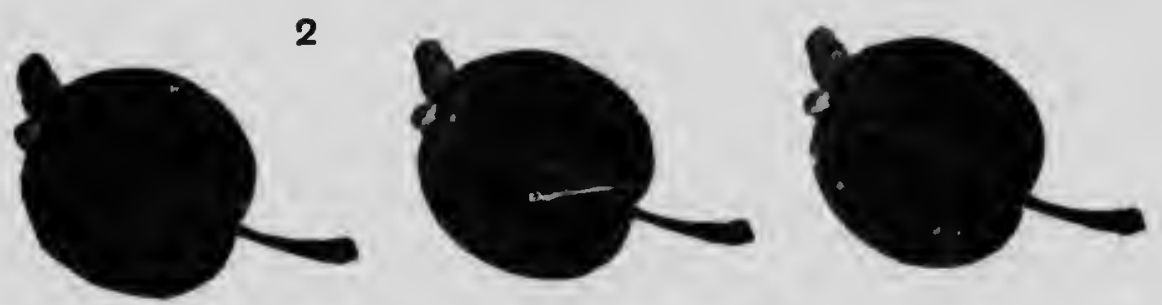

FIg. 1. -Apples three-quarters grown, showing early work of nyinphs. (Original.)

Fig. 2, -Full grown plums Injured by adults. (OrIginal.) 


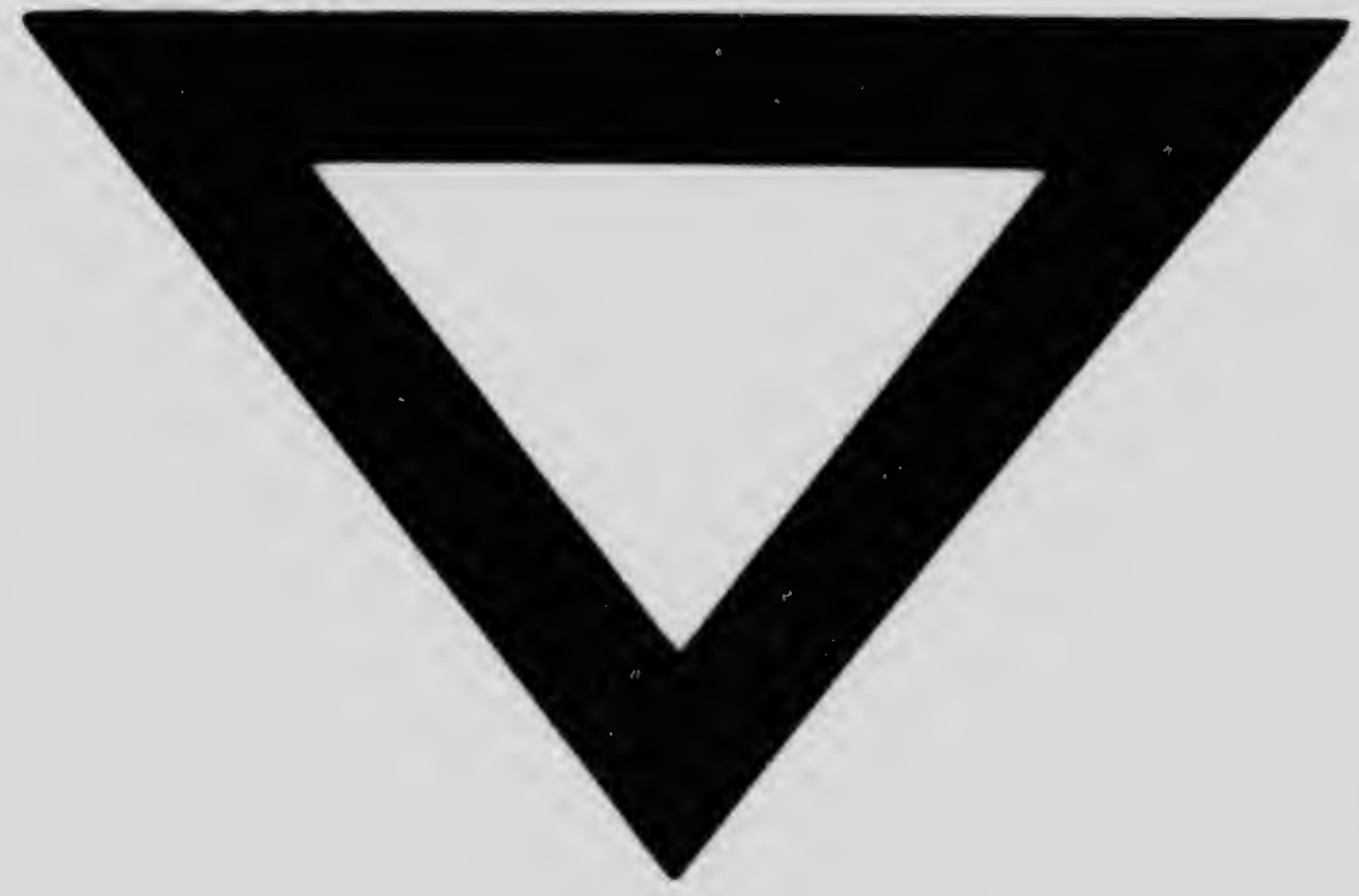

